\title{
Progressing haemorrhagic stroke: categories, causes, mechanisms and managements
}

\author{
Shiyu Chen $\cdot$ Liuwang Zeng $\cdot$ Zhiping Hu
}

Received: 7 January 2014/Revised: 14 February 2014 / Accepted: 17 February 2014/Published online: 5 March 2014

(C) The Author(s) 2014. This article is published with open access at Springerlink.com

\begin{abstract}
Haemorrhagic stroke is a severe stroke subtype with high rates of morbidity and mortality. Although this condition has been recognised for a long time, the progressing haemorrhagic stroke has not received adequate attention, and it accounts for an even worse clinical outcome than the nonprogressing types of haemorrhagic stroke. In this review article, we categorised the progressing haemorrhagic stroke into acute progressing haemorrhagic stroke, subacute haemorrhagic stroke, and chronic progressing haemorrhagic stroke. Haematoma expansion, intraventricular haemorrhage, perihaematomal oedema, and inflammation, can all cause an acute progression of haemorrhagic stroke. Specific 'second peak' of perihaematomal oedema after intracerebral haemorrhage and 'tension haematoma' are the primary causes of subacute progression. For the chronic progressing haemorrhagic stroke, the occult vascular malformations, trauma, or radiologic brain surgeries can all cause a slowly expanding encapsulated haematoma. The mechanisms to each type of progressing haemorrhagic stroke is different, and the management of these three subtypes differs according to their causes and mechanisms. Conservative treatments are primarily considered in the acute progressing haemorrhagic stroke, whereas surgery is considered in the remaining two types.
\end{abstract}

Keywords Intracerebral haemorrhage · Progressing haemorrrahagic stroke · Early neurologic deterioration .

Haematoma expansion - Perihaematomal oedema $\cdot$ Chronic encapsulated intracerebral haematoma

S. Chen $\cdot$ L. Zeng $\cdot$ Z. Hu $(\bowtie)$

Department of Neurology, Xiangya Second Hospital, Central

South University, 139 Renmin Road, Changsha 410011, Hunan,

People's Republic of China

e-mail: huzhipingxy@gmail.com

\author{
Abbreviations \\ CT Computed tomography \\ ICH Intracerebral haemorrhage \\ CTA Computed tomography angiography \\ PET-CT Positron emission tomography-computed \\ tomography \\ rFVIIa Recombinant factor VIIa \\ FFP Fresh frozen plasma \\ CEICH Chronic encapsulated intracerebral haematoma
}

\section{Introduction}

Haemorrhagic stroke, which accounts for $10-20 \%$ of all of the new strokes that occur every year [78], has a 1-month mortality rate of approximately $40 \%$ [164]. Although it has drawn the attention of researchers because of the high rates of morbidity and mortality, the outcomes and prognosis of intracranial haemorrhage have not improved significantly during the last several decades [142, 164].

Progressing stroke, also known as progressive stroke, stroke-in-progression, stroke-in-evolution, and deteriorating stroke, has been a clinical concept for a long time [27, 54]. Progressing stroke happens often within 36-72 h, with marked deterioration in clinical manifestations measured by the Scandinavian Stroke Scale or the Canadian Stroke Scale [83, 117, 154]. This concept was traditionally limited to ischaemic stroke [116], and haemorrhagic stroke was often ruled out in the initial studies of progressing stroke [84]. However, evidence has shown that a progression also exists in the haemorrhagic stroke [27, 54, 113]. Several researchers have shown that primary haemorrhagic stroke is more often associated with progression than ischaemic stroke [18] and that early deterioration is associated with a poorer outcome [93]. 
Early neurological deterioration of intracerebral haemorrhage has been recognised in many patients with haemorrhagic stroke [30, 46, 93, 100, 113]. As with progressing ischemic stroke, a deterioration of clinical signs and symptoms often happens within 24-72 h with intracerebral haemorrhage and is associated with haematoma expansion [30], perihaematomal oedema [46], intraventricular haemorrhage [100], and inflammation [155]. The expansion of haematoma may account for most of the progression [100, $113,150]$. Additionally, in the second to third weeks after the onset of intracerebral haemorrhage, many patients may undergo a deterioration of symptoms after the initial alleviation by conservative management, which indicates a subacute progression [171, 182]. Furthermore, the progression of haemorrhage may appear to be a chronic form, in which the gradual formation of an encapsulated intracerebral haematoma may cause progressive neurologic deficits over weeks or months $[64,69,133]$. Therefore, the concept of progressing haemorrhagic stroke should be separated from the progressing ischaemic stroke, because the causes, pathogenesis, mechanisms, manifestations and management of the former all differ from the latter.

In this review article, we proposed the concept of progressing haemorrhagic stroke and summarised the three categories of progressing haemorrhagic stroke, which are as follows: acute progressing haemorrhagic stroke, subacute progressing haemorrhagic stroke and chronic encapsulated intracerebral haematoma. We explored several aspects of their causes, mechanisms and management.

\section{Acute progressing haemorrhagic stroke}

\section{Clinical features}

Many researchers have observed an early neurological deterioration in spontaneous intracerebral haemorrhage. Despite the difference in the diagnostic criteria of early neurological deterioration, the studies have all shown a significant deterioration that occurs in 22.9-37\% of the patients [46, 100, 113, 150, 155]. In several retrospective studies, an ICH score of $>2$, white blood cell count of $>10,000$ cells $/ \mathrm{mL}^{3}$, an initial Glasgow Coma Scale score of $<14$, large haemorrhage volume with significant mass effect on initial CT scan, haematoma expansion and intraventricular haemorrhage were shown to be associated with early neurological deterioration [46, 150, 155]. In a prospective study of 46 patients, Mayer et al. [113] proved that larger initial haemorrhages and marked initial mass effect predicted early neurological deterioration. A prospective study of 266 patients by Leira et al. [100] showed that on admission to the hospital, body temperature of $37.5^{\circ} \mathrm{C}$, increased neutrophil count and serum fibrinogen levels of $>523 \mathrm{mg} / \mathrm{dL}$ could all independently predict neurological deterioration, whereas at $48 \mathrm{~h}$, early ICH growth, intraventricular bleeding and highest systolic blood pressure were associated with neurological deterioration. Patients who experienced early neurological deterioration demonstrated significantly increased morbidity and mortality rates than those who did not [46, 100, 113]. The studies that focused on the early neurological deterioration are listed in Table 1.

\section{Causes}

\section{Haematoma expansion}

Haematoma expansion refers to the expansion of the haemorrhagic volume within the first 3-72 h, mostly within $6 \mathrm{~h}$ [50, 87]. Detected by neuroimaging methods, this expansion occurs in $13-40 \%$ in all of the reported patients $[20,51,88]$. The definition of haematoma expansion is not universally agreed upon, and the commonly used definition is an increase in the volume of intraparenchymal haemorrhage of $>33 \%$ between the baseline and the repeated CT, increase of volume by $\geq 12.5 \mathrm{~cm}^{3}$ or by $\geq 1.4$ times [20, 50, 87]. Haematoma expansion not only accounts for a major part of the acute progression in the acute phase of intracerebral haemorrhage [46, 100, 113], but is also independently associated with a poor outcome [20, 30, 32, 51].

\section{Intraventricular haemorrhage}

Intraventricular extension of haemorrhage is another deteriorating factor of early $\mathrm{ICH}[100,155]$. Intraventricular extension may occur simultaneously with $\mathrm{ICH}$ or within 24-72 $\mathrm{h}$ after the onset of initial $\mathrm{ICH}$, in $20-55 \%$ of all ICH patients [106, 152]. Steiner et al. [152] and Bhattathiri et al. [16] all showed that ICH patients with intraventricular haemorrhage had a worse functional outcome compared to those without intraventricular hemorrhage. Adjusting for the ICH score and haematoma expansion, intraventricular haemorrhage is still associated with a higher mortality rate within the patients' hospitalisation stay [106].

\section{Perihaematomal oedema}

Perihaematomal oedema volume increases significantly after onset within the first $24 \mathrm{~h}$ after spontaneous ICH [56]. The chronological CT images showed that perihaematomal oedema increased rapidly within 3 days after onset and reached its initial peak in the fourth or fifth day [79, 165]. The highly evident initial mass effect could also contribute 
Table 1 Early neurological deterioration occurrence in multiple studies

\begin{tabular}{|c|c|c|c|c|}
\hline References & $\begin{array}{l}\text { Type of } \\
\text { study }\end{array}$ & Cases & $\begin{array}{l}\text { END occur } \\
\text { in }\end{array}$ & Factors associated with END \\
\hline $\begin{array}{l}\text { Mayer } \\
\text { et al. } \\
{[113]}\end{array}$ & Prospective & 46 & $15(33 \%)$ & $\begin{array}{l}\text { Causes: } \\
\text { Haematoma enlargement, perihaematomal oedema, } \\
\text { infarction; } \\
\text { Predictive factors: } \\
\text { Larger initial haemorrhages, marked mass effect }\end{array}$ \\
\hline $\begin{array}{l}\text { Flemming } \\
\text { et al. [46] }\end{array}$ & Retrospective & 61 & $16(26 \%)$ & $\begin{array}{l}\text { Predictive factors: } \\
\text { Glasgow Coma Scale score }<14 \text {, Imaging } \\
\text { characteristics such as haemorrhage volume } \\
>60 \mathrm{~mL} \text {; shift of the septum pellucidum; } \\
\text { effacement of the contralateral ambient cistern; } \\
\text { widening of the contralateral temporal horn; } \\
\text { Causes: } \\
\text { Haematoma enlargement, perihaematomal oedema }\end{array}$ \\
\hline $\begin{array}{l}\text { Leira et al. } \\
{[100]}\end{array}$ & Prospective & 266 & $61(22.9 \%)$ & $\begin{array}{l}\text { Predictive factors: } \\
\text { On admission: Body temperature of } 37.5^{\circ} \mathrm{C} \text {, } \\
\text { neutrophil count, serum fibrinogen levels of } \\
523 \mathrm{mg} / \mathrm{dL} \text {; } \\
\text { At } 48 \mathrm{~h} \text { : early ICH growth, intraventricular bleeding, } \\
\text { highest systolic blood pressure }\end{array}$ \\
\hline $\begin{array}{l}\text { Sorimachi } \\
\text { et al. } \\
\text { [150] }\end{array}$ & Retrospective & 184 & $19(10 \%)$ & $\begin{array}{l}\text { Causes: } \\
\text { Haematoma enlargement; hydrocephalus; convulsion; } \\
\text { pneumonia }\end{array}$ \\
\hline $\begin{array}{c}\text { Sun et al. } \\
\text { [155] }\end{array}$ & Retrospective & 83 & $31(37 \%)$ & $\begin{array}{l}\text { Predictive factors: } \\
\text { Midline shift on imaging; ICH score; white blood cell } \\
\text { count }>10,000 / \mathrm{mL}^{3}\end{array}$ \\
\hline
\end{tabular}

END early neurologic deterioration associated with liver disease [87] and the amount of alcohol consumption [50], and negatively associated with the level of fibrinogen [50]. Warfarin use was associated with both haematoma expansion and intraventricular haemorrhage [17, 45, 47]. Broderick et al. and Yildiz et al. found a correlation between antiplatelet therapy and haematoma expansion [19, 180]. The low serum LDL cholesterol level was also reported to be associated with a higher haematoma expansion rate; researchers think that this association is related to the function of LDL to maintain vascular integrity [144].

\section{Hypertension}

Kazui et al. [87] showed that an interaction of hyperglycaemia and hypertension on hospital admission was associated with haematoma expansion. Takeda et al. [159] showed that blood pressure of $>160 \mathrm{mmHg}$ measured at $1.5 \mathrm{~h}$ after admission was significantly associated with haematoma expansion. Steiner et al. [152] also showed that increased baseline blood pressure was associated with intraventricular haemorrhage growth. Sykora et al. [156] showed that decreased baroreflex sensitivity was significantly correlated with increased blood pressure fluctuation and was an independent predictor of relative oedema. The 
antihypertensive therapies, which have become routine therapeutic methods in $\mathrm{ICH}$, have received fair results in reducing haematoma enlargement, which will be described subsequently [8, 90, 137].

\section{Hyperglycaemia}

Hyperglycaemia on admission is an important predisposing factor for haematoma expansion [19]. Querish et al. [138] analysed the blood glucose of the ICH patients measured repeatedly after hospital admission over 3 days, and the results showed that those with increasing blood glucose had increased haematoma expansion and perihaematomal oedema, compared to those with decreasing blood glucose measurements. A linear correlation of intraventricular haemorrhage and hospital admission hyperglycaemia has also been detected by Appelboom et al. [9]. In an experimental model, Liu et al. [104] showed that hyperglycaemia increased haematoma expansion through the effect of increased kallikrein, which inhibits platelet aggregation. Hyperglycaemia may result from a history of diabetes, or stress reaction of ICH [170]. Many studies have shown that hyperglycaemia at the time of hospital admission is associated with early mortality and poor outcome in ICH patients $[14,89,98,170]$.

\section{Haemorrhagic location}

For patients with lobar ICH, an early mortality was associated with the involvement of the inferior parietal lobule, posterior insula and posterolateral thalamus, whereas for patients with basal ganglia ICH, early mortality was associated with a large region extending from the cortex to the brainstem [97]. Intraventricular haemorrhage extension is correlated with the primary location of ICH [152]. A retrospective study by Hallevi et al. [66] showed that thalamic and caudate locations had the highest intraventricular haemorrhage frequency. Lee et al. [97] also detected a higher incidence of intraventricular haemorrhage in the thalamic and basal ganglia. Intraventricular haemorrhage patients including the third and fourth ventricle or ICH patients with insular involvement are reported to have lower baroreflex sensitivity than the patients without these involvements, suggesting that involvement of these sites could contribute to impairment of autonomic blood pressure regulation [157, 158]. Hypertensive responses can be exaggerated and additive because of the impaired baroreceptor sensitivity [135].

\section{Vasogenic oedema}

Early perihaematomal oedema could be vascular in origin $[22,23]$. Several animal experiments have confirmed that early oedema formation occurs despite an intact bloodbrain barrier [168]. The oedema occurrence and the volume in thrombolysis-related patients with ICH are all less frequently observed than those seen in patients with spontaneous $\mathrm{ICH}$, indicating that an existence of a clot is necessary for the presence of hyperacute oedema [55]. Blood clot retraction could force the serum into the perihaematomal space to form vasogenic oedema [178]. Butcher et al. [23] investigated 21 patients with ICH using perfusion-weighted MRI and diffusion-weighted MRI within $10 \mathrm{~h}$; they found that water diffusion in the perihaematomal region was significantly increased and was independently correlated with perihaematomal oedema volume, and they suggested that the hyperacute oedema was, for the most part, plasma-derived.

\section{Cytotoxic factors and inflammation}

Thrombin, which is formed in the activated coagulation cascade in the early phase of ICH, primarily contributes to the development of early perihaematomal oedema [177] by activating Src kinase phosphorylation to destroy the bloodbrain barrier via its protease-activated receptors [103]. Several animal studies have shown that thrombin could induce apoptosis of neurons and astrocytes [38], potentiate glutamate NMDA receptor function [10, 57], activate microganglia [119], activate autophagy process [71] or induce TNF-alpha release [73]. Also, the activated inflammation cascade may contribute to brain damage. Heme oxygenase, cellular fibronectin, interleukin-6, tumour necrosis factor-alpha, matrix metalloproteinase- 9 (MMP-9) overexpression are all shown to be associated with haematoma expansion [48, 86, 149, 169]. Lee et al. [99] showed that by blocking the MMP-9 modulations in the experimental ICH of rats, a reduction of haematoma expansion can be observed (Fig. 1).

Each of the predisposing factors contributes to the pathogenesis of acute progressing haemorrhagic stroke, whereas several factors affect each other. The interaction of all causes promotes the progressing together.

Prediction of acute progressing haemorrhagic stroke

The predisposing factors described all predict the progression of haemorrhagic stroke. Additionally, researchers have tried to develop more effective ways to predict the progressing haemorrhagic stroke. Because haematoma expansion accounts for the majority of acute progressing, the major explorations on predictions are on haematoma expansion. Several radiological methods have been developed.

Haematoma enlargement is less likely to occur in those who have a long interval ( $>6 \mathrm{~h})$ from onset to first CT [12, 
Fig. 1 Mechanism of acute progressing haemorrhagic stroke

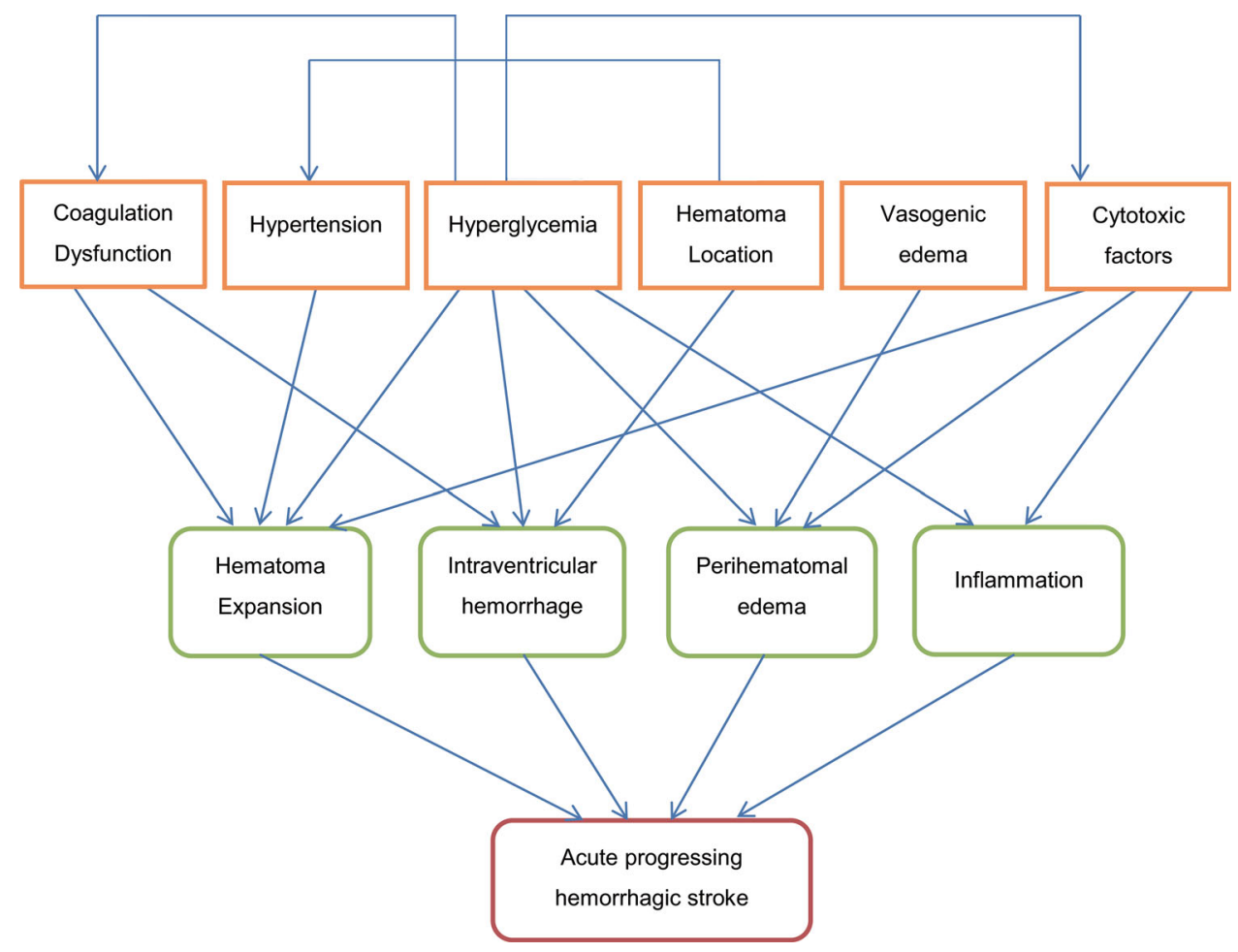

87]. ICH volume on baseline CT was positively associated with both haematoma expansion and intraventricular haemorrhage occurrence [66, 129]. A meta-analysis concluded that a smaller initial haematoma is less likely to expand [39].

Researchers have described the predictive radiological signs of the initial CT on admission to the hospital. A CT angiography 'spot sign' has proven to be an effective means for predicting haematoma growth $[21,35,166]$. The concept of the CTA 'spot sign' has evolved from the initial concept of contrast extravasation on postcontrast CT and was thought to represent ongoing bleeding [21, 101]. It was defined to be one or more foci of enhancement within the haematoma on CTA source images [166]. Four criteria have been proposed to identify the 'spot sign': (1) serpiginous or spot-like appearance within the margin of a parenchymal haematoma without connection to an outside vessel; (2) a contrast density of $>1.5 \mathrm{~mm}$ in diameter in at least one dimension; (3) a contrast density (Hounsfield units, $\mathrm{HU}$ ) of at least double that of the background haematoma; and (4) no hyperdensity at the corresponding location on non-contrast CT [163].

A multicentre, prospective, observational study has shown that the 'spot sign' significantly predicted haematoma expansion with a sensitivity of $51 \%$ and specificity of $85 \%$, and was associated with a worse prognosis and increased mortality [35]. Several researchers have suggested that postcontrast CT extravasation could be an alternate to add the predictive value and sensitivity of spot sign $[40,65]$. Furthermore, Almandoz et al. have developed a 'spot sign score' system, involving spot sign numbers, maximal axial dimension and maximal attenuation. The higher scores are associated with higher in-hospital mortality and poor outcome [33,34]. A clinical trial is being conducted to test its predicting value in early haematoma growth [59] (Fig. 2).

However, although ASA/AHA recommended CTA or contrast CT to identify the patients at risk for haematoma expansion [122], neither of them is a routinely performed examination at the time of hospital admission in many institutions. Haematoma density heterogeneity could be a substitute for the prediction of haematoma expansion. Haematoma heterogeneity refers to the irregularity of shape and density of the initial haematoma on the CT scan, and researchers have found an association between haematoma heterogeneity and haematoma expansion [13, 81]. Takeda et al. [159] concluded that the presence of haematoma volume above $16 \mathrm{~mL}$, haematoma heterogeneity and $1.5 \mathrm{~h}$ of a systolic blood pressure above $160 \mathrm{mmHg}$ together increased the likelihood of haematoma expansion to approximately $59 \%$. Although its definition was traditionally arbitrary, Ji et al. [81] defined the haematoma heterogeneity as a difference of over $20 \mathrm{HU}$ in CT value between two regions exceeding $10 \mathrm{~mm}^{2}$ in area. Barras et al. used quantitative CT densitometry to measure mean attenuation, square root of variance, coefficient of variation, skewness and kurtosis of the attenuation distribution of the haematoma; they found that the coefficient of 


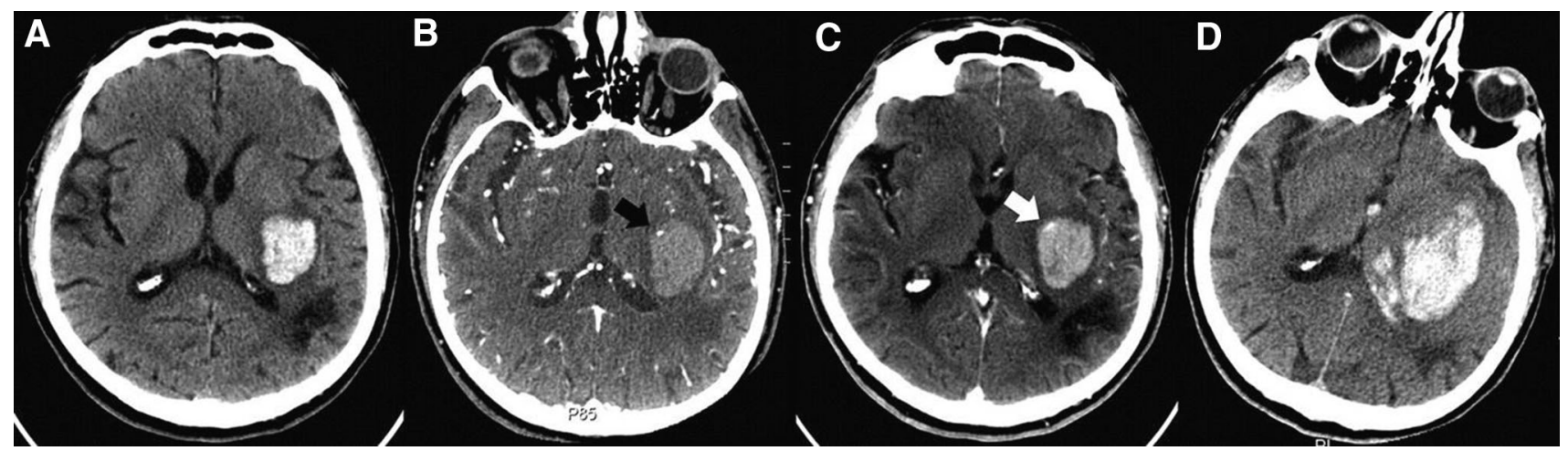

Fig. 2 Patient with 'spot sign,' demonstrating extravasation and haematoma expansion [166]. Reproduced from Wolters Kluwer Health with permission
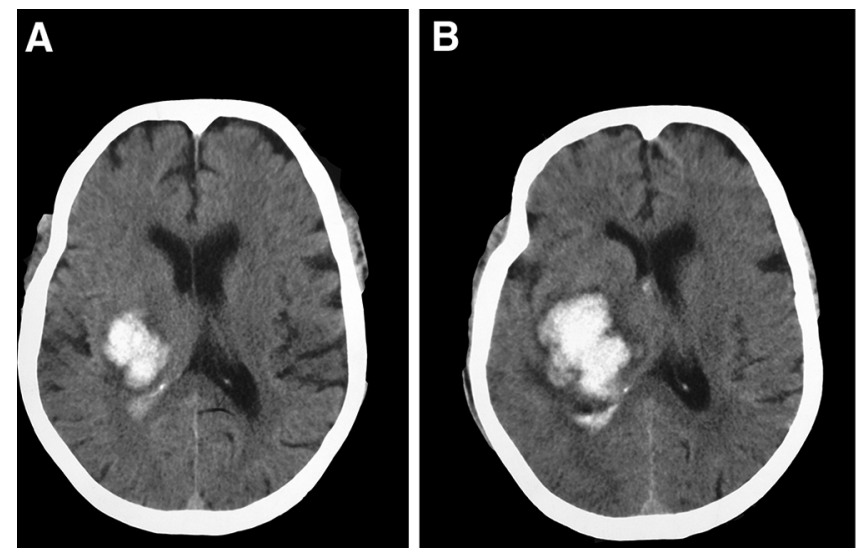

Fig. 3 Haematoma heterogeneity and haematoma growth border. These two patients were admitted to our hospital with the impression of spontaneous ICH. Patient 1: a CT on admission shows haematoma heterogeneity with an initial haematoma volume of $15 \mathrm{~mL}$.

variation and the square root of variance, along with the basic haematoma volume, are predictors of greater growth. They suggested that quantitative CT densitometry can be used to identify haematoma heterogeneity [12]. Additionally, Ji et al. described a characteristic 'haematoma enlargement border', which was defined as an obvious boundary between high- and low-density regions within the primary haematoma on the CT. The haematoma enlargement border reflects on-going bleeding and its presence may be associated with potential haematoma expansion [81] (Fig. 3).

Managements of acute progressing haemorrhagic stroke

\section{Osmotherapy}

Osmotherapy with mannitol is often applied in the acute phase of ICH to control the increased intracranial pressure. However, mannitol may have the possibility of aggregating haematoma expansion or perihaematomal oedema, because
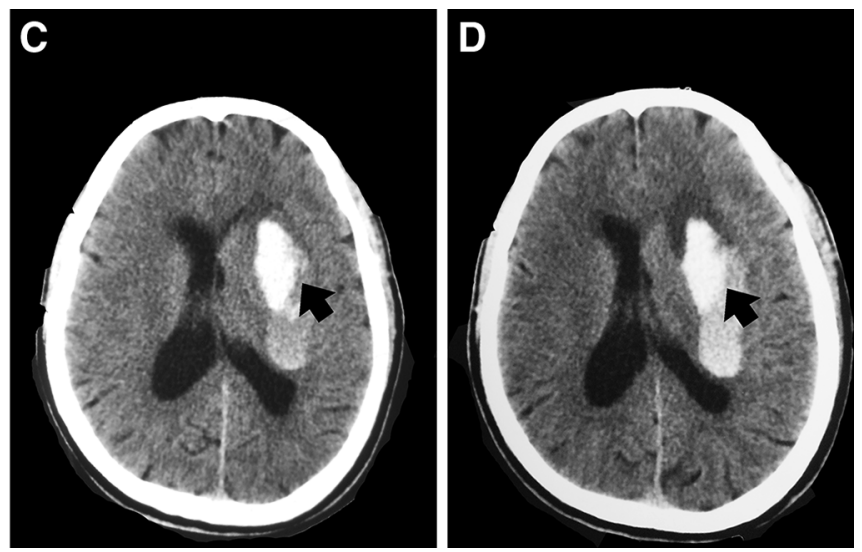

b Repeated CT after $32 \mathrm{~h}$ shows a haematoma volume of $30 \mathrm{~mL}$. Patient 2: c CT on admission shows haematoma growth border (black arrow). d Repeated CT after $10 \mathrm{~h}$ shows haematoma expansion with increased midline shift

it may open the blood-brain barrier $[29,141]$ or reverse the osmotic concentration gradient between the oedematous brain and plasma [85]. In a randomised controlled trial, 128 patients with ICH were treated either with mannitol or sham infusion in their early stage of hospitalisation, and the result showed no difference in one-month mortality and secondary outcome [118]. The Cochrane systemic review, including two trials of mannitol for $\mathrm{ICH}$, did not find significant differences in mortality and morbidity between treatment groups and controls [15]. In those without significant intracranial hypertension or mass effect, mannitol should not be used but close monitoring should be applied [136].

For a patient with an increased ICP, elevating the head to 30 degrees, giving $1.0-1.5 \mathrm{~g} / \mathrm{kg}$ of $20 \%$ mannitol by a rapid infusion, and hyperventilating the patient to a $\mathrm{pCO}_{2}$ of $28-32 \mathrm{mmHg}$ are the usual management protocols [112]. Hypertonic saline is an alternative choice for decreasing intracranial pressure [91, 139]. Wagner et al. [167] treated ICH patients with spontaneous lobar and 
basal ganglia/thalamic bleeding with continuous hypertonic saline infusion within $72 \mathrm{~h}$, and the relative oedema volume and the occurrence of intracranial pressure crisis had significantly decreased.

\section{Blood pressure control}

The protective effect of anti-hypertensive therapy in ICH has been broadly explored. A retrospective series of 76 patients by Ohwaki et al. showed that systolic blood pressure (SBP) of $\geq 160 \mathrm{mmHg}$ was significantly associated with haematoma enlargement compared to those of $\leq 150 \mathrm{mmHg}$, and efforts to lower SBP below $150 \mathrm{mmHg}$ may prevent this risk [130]. Also, several clinical trials have been conducted. The Intensive Blood Pressure Reduction in Acute Cerebral Hemorrhage Trial (INTERACT) randomised 404 patients to receive either standard blood pressure management ( $\mathrm{SBP}<180 \mathrm{mmHg}$ ) or more aggressive blood pressure management (SBP $<140 \mathrm{mmHg}$ ); the results showed a decrease in haematoma expansion by $2.80 \mathrm{~mL}$, with no significant difference in perihaematomal oedema [8]. The results of the INTERACT phase 2 trail, performed on 2,839 patients, showed no significant reduction of haematoma expansion but significant improved functional outcome in the intensive blood pressure lowering group compared to the control group [7]. The Antihypertensive Treatment of Acute Cerebral Hemorrhage (ATACH) study randomised 60 patients to receive intravenous nicardipine hydrochloride to three systolic blood pressure reduction goals: $170-199,140-169$, or $110-139 \mathrm{mmHg}$. The post hoc analysis results showed that patients with a lower blood pressure were less likely to have haematoma expansion, perihaematomal oedema, and a poor 3-month outcome [137].

Presently, based on the existing incomplete evidence, AHA/ASA guidelines recommend that for patients with SBP of $>200 \mathrm{mmHg}$ or MAP of $>150 \mathrm{mmHg}$, continuous intravenous infusion to reduce the BP should be applied, with BP monitoring every $5 \mathrm{~min}$. For SBP of $>180 \mathrm{mmHg}$ or MAP of $>130 \mathrm{mmHg}$ in patients with a likelihood of ICP elevation, reducing BP while simultaneously maintaining a cerebral perfusion pressure of $\geq 60 \mathrm{mmHg}$ is recommended. If there is no evidence of elevated ICP, then a modest reduction of BP (e.g., MAP of $110 \mathrm{mmHg}$ or a target $\mathrm{BP}$ of $160 / 90 \mathrm{mmHg}$ ) with a re-examination every $15 \mathrm{~min}$ is recommended [121].

\section{Coagulopathy reversal}

Because coagulopathy contributes to the early progression of haemorrhagic stroke, ultra-early haemostatic therapies have been introduced to stabilise the condition and reduce the progressing [109]. For those patients who have been taking oral anticoagulants, such as warfarin, it is necessary to withdraw the drug and initiate a rapid reversal therapy, because it contributes to both a higher incidence of haematoma expansion $[45,47]$ and a higher mortality rate [145]. However, because warfarin may only contribute to rather than cause a role in the pathogenesis of ICH [146], discontinuing warfarin therapy with the administration of vitamin $\mathrm{K}$ is not sufficient. PCC [5, 24], rFVIIa [5], or FFP [60] are often considered [3, 4, 107]. Schlunk et al. [148] compared rFVIIa and PCC use in experimental warfarinassociated ICH and showed that they both could reduce the haematoma enlargement, with no significant difference in the reduction. A retrospective study showed that PCC was effective in reducing the fatality of warfarin-associated ICH [76]. Huttner et al. [77] retrospectively reviewed 55 patients who received PCC alone or in combination with FFP or vitamin $\mathrm{K}(n=31)$, with FFP alone or in combination with vitamin $\mathrm{K}(n=18)$, or with vitamin $\mathrm{K}$ as a monotherapy $(n=6)$, and the results showed that the incidence and the extent of haematoma growth were lower in patients receiving PCC compared with FFP and vitamin $\mathrm{K}$. However, in a prospective research, de Leciñana et al. sought to detect the effect of anticoagulation reversal treatment in vitamin $\mathrm{K}$ antagonist-associated $\mathrm{ICH}$, and the results showed that of anticoagulation reversal treatments-PCC with or without vitamin K, vitamin K monotherapy, or FFP with or without vitamin $\mathrm{K}$-none were related to reduced mortality or functional outcome [31].

For anticoagulants, such as dabigatran, rivaroxaban or lepirudin, the previous antithrombotic therapy could also be applied, although there is no consensus for the treatment protocol $[3,95]$. Because the role of antiplatelets in $\mathrm{ICH}$ has not been established, there is no recommended therapy for reversal, whereas the application of desmopressin acetate was reported by several researchers [3].

Recombinant activated factor VII for ICH has been explored in many studies. The Factor VII for Acute Intracerebral Hemorrhage phase IIB and phase III trials both showed that with an increased dose of rFVIIa, the haematoma growth volume decreased $[110,111]$. However, the phase III trial showed that rFVII neither reduced mortality nor improved functional outcome [110]. The Cochrane systemic review, including six clinical trials with 975 patients receiving haemostatic drugs (two with epsilon-aminocaproic acid and 973 with rFVIIa), found no evidence of a reduction of death or dependence by haemostatic drugs [6]. Tranexamic acid is another hemostatic agent, and two multicentered clinical trials on tranexamic acid for ICH are presently recruiting patients $[1,115]$. 


\section{Blood glucose control}

Although both diabetes and hyperglycaemia in non-diabetic patients were shown to have a higher early mortality, there are no agreed criteria of blood glucose control in the acute phase of ICH [131]. A prospective study by Godoy et al. [58] showed that insulin application within the first $12 \mathrm{~h}$ after ICH onset attenuated the association of hyperglycaemia with mortality. Ho et al. [70] selected 12 patients who underwent surgeries for spontaneous ICH and randomised them to intermittent or intensive continuous insulin infusion to maintain the blood glucose level between 4.0 and $8.0 \mathrm{mmol} / \mathrm{L}$; the results showed that the continuous insulin infusion group had a lower MAP and ICP postoperatively. A randomised, controlled trial aimed at detecting whether $24 \mathrm{~h}$ of intensive glucose control by glucose-potassium-insulin infusions could reduce mortality or improve functional outcome failed to show a positive result, although the trial mainly focused on patients with ischemic stroke; the data of patients with ICH were not individually reported [62].

Presently, the AHA/ASA guidelines recommended that blood glucose should be maintained within normal range for patients with acute ICH [122].

\section{Anti-inflammation therapy}

Randomised trials have failed to demonstrate the efficacy of corticosteroids and, therefore, corticosteroid therapy is not recommended to treat patients with ICH $[132,161]$. There are no other reported clinical trials that target the inflammatory cascade, although in several animal examinations, protease-activated receptor antagonists, iron chelators, $\mathrm{N}$-acetylheparin, heme degradation inhibitors and antioxidants have been used [61, 74, 82].

\section{Surgeries}

Whether surgeries are beneficial for the patients with early haemorrhagic stroke has been controversial for a long time [42]. A retrospective analysis of Morioka suggested that surgically treated patients in the early stages of ICH demonstrated a better outcome [123]. The Surgical Trial in Intracerebral Hemorrhage (STICH) trial randomised 1,033 patients to receive either early surgery or conservative treatment, and the results showed no benefit of early surgery in patients with ICH [114]. However, the STICH trial neither individually explored those who are specifically thought to be more suitable for surgeries nor the results of certain types of surgery [112]. A meta-analysis involving 10 trials concluded that surgery added to medical management reduced the mortality rate and dependence after ICH [134]. Another meta-analysis that enrolled eight studies revealed that certain patients might benefit from surgery: within $8 \mathrm{~h}$ of onset, a volume of the haematoma between 20 and $50 \mathrm{~mL}$, Glasgow Coma Score between 9 and 12, patients' age range between 50 and 69 years, and superficial haematomas with no intraventricular haemorrhage [63].

The surgical methods include craniotomy, decompressive craniectomy, stereotactic aspiration, endoscopic aspiration, and catheter aspiration aimed at removing the clot $[42,63]$. Certain types of surgeries may decrease the early progression of ICH. Rabinstein et al. [140] reviewed 26 patients with rapidly worsening symptoms with a significant mass effect who received craniotomy, and $22 \%$ of the patients gained functional independence. Decompressive craniectomy is often combined with haematoma evacuation in treating ICH [160]. Fung et al. reviewed 12 patients who received decompressive craniectomy only, with 15 matched controls who were treated conservatively; three patients $(25 \%)$ of the treatment group died versus eight of $15(53 \%)$ of the control group, which shows feasibility for decompressive craniectomy without evacuation in treating ICH [53]. Because the clot and thrombin were the primary predisposing factors of the perihaematomal oedema development, Mould et al. conducted the Minimally Invasive Surgery and rtPA in ICH evacuation (MISTI) trial to evaluate the effectiveness of the clot lysis method. Their trial comprised 81 patients with minimally invasive surgery combined with recombinant tissue plasminogen activator administration and 42 patients with standard therapy; the results showed that both the haematoma volume and perihaematomal oedema were lower in the surgical group [124]. A meta-analysis by Zhou et al. involving 12 highquality randomised, controlled trials concluded that minimally invasive surgery, especially stereotactic aspiration, could significantly reduce the early mortality of patients with $\mathrm{ICH}$, and those with a superficial haematoma between 25 and $40 \mathrm{~mL}$ might most likely benefit from such surgeries [183].

For intraventricular extension of ICH, the removal of the blood clot in animal experiments showed benefits by controlling ICP, improving the level of consciousness and preventing tissue inflammation [67]. Compared to conservative therapy, extraventricular drainage, especially with fibrinolytic agents such as rtPA, significantly improved the case fatality rate and outcome [129]. rtPA may accelerate the clot lysis [126], but it also has the risk of aggregating bleeding. Naff et al. [125] tested removing the intraventricular haemorrhage with a catheter-delivered rtPA in the Clot Lysis: Evaluating Accelerated Resolution of IVH (CLEAR-IVH) trial; the results showed that the mortality rate, ventriculitis occurrence and bleeding events were all significantly lower in the treatment group, without significant changes in the systemic haematologic status [68]. 


\section{Stroke unit}

The observational study of Diringer and Edwards [37] showed that $\mathrm{ICH}$ patients admitted to a neuro intensive care unit is associated with reduced mortality rate, compared to those admitted to general ICU. Organized stroke care, or stroke unit, is effective in reducing mortality, institutionalization, and dependence in treating stroke patients [153], and it is recommended as a primary care model for stroke in many guidelines [41, 80, 128]. A recent systemic review including eight trials also showed that for $\mathrm{ICH}$ patients, stroke unit care was associated with a significant reduction of death or dependency [94].

\section{Subacute progressing haemorrhagic stroke}

Clinical features

Several of the patients with intracerebral haemorrhage develop late-onset deterioration, which often occurs during the second and third weeks. Although complications such as re-bleeding, deep vein thrombosis, and pneumonitis may occur, the subacute progression of haemorrhagic stroke should primarily be attributed to the increased mass effect produced by secondary oedema $[11,124]$. As previously described, perihaematomal oedema has two peaks: in the fourth or fifth days, or during the second and third week [26, $165,182]$. This special feature of ICH is consistent with the progression of perihaematomal oedema after the onset of ICH [26, 79]. Subacute natural progression has not been reported much, and it is hard to identify in the beginning.

\section{Causes}

\section{Delayed perihaematomal oedema}

Inaji et al. [79] investigated the chronological changes of perihaematomal oedema in 14 patients with CT scan and found that its volume increased rapidly within 3 days after haemorrhage, subsequently increased slowly until day 14, and decreased thereafter. Consistently, Venkatasubramanian et al. [165] investigated 27 patients prospectively with MR imaging and found that oedema volume growth was fastest in the first 2 days, and continued until $12 \pm 3$ days. By 2 weeks, the haemorrhage volume decreased, whereas oedema and haemorrhage plus oedema volumes significantly increased [11, 52]. A retrospective study involving 490 patients revealed that after admission to the hospital, the perihaematomal oedema increased, whereas the haematoma volume decreased, and the mass effect almost doubled between 7 and 11 days, which could cause an increase in ICP and secondary clinical deterioration [151].
Tension haematoma

A specific 'tension haematoma', reported by Chinese scholars, might also develop in this phase. The patients often have a history of hypertension. The main features of tension haematoma are as follows: a sudden increase of ICP after the initial alleviation during conservative therapy, with a CT scan showing large regions of low density, isodensity or mixed-density near the initial haemorrhage [75]. A contrast CT could be used to distinguish perihaematomal oedema from tension haematoma. The ringenhancement [172] on contrast CT at that time indicated the formation of tension haematoma, with regions interior to the ring-enhancement demonstrated tension haematoma, whereas the regions exterior to the ring-enhancement demonstrated perihaematomal oedema [105] (Fig. 4).

Mechanisms

\section{Red blood cell lysis and iron toxicity}

Different from the initial oedema, the delayed perihaematomal oedema is mainly caused by erythrocyte lysis [72, 177]. It has been observed in $\mathrm{ICH}$ patients that during the second week, the perihaematomal oedema increases in size simultaneously with the lysis of the clot [173]. In several animal experiments, the intracerebral infusion of packed erythrocytes to the ICH rats caused oedema 3 days later [176], whereas the intracerebral infusion of lysed erythrocytes caused oedema within $24 \mathrm{~h}[175,176]$, similar to the infusion of haemoglobin [174]. Furthermore, the upregulation of the primary heme degradation enzyme, heme oxygenase-1 (HO-1), has been observed in experimental ICH [169], simultaneously inhibiting HO-1 attenuated the brain oedema [174]. The infusion of haemoglobin degradation products, such as heme and $\mathrm{Fe}^{2+}$, could also induce brain oedema, whereas the oedema caused by the haemoglobin infusion could be attenuated by the infusion of iron chelator deferoxamine, indicating that iron degraded from haemoglobin is the primary cytotoxic factor that contributed to the delayed brain oedema [74].

\section{Granulation tissue formation}

Formation of tension haematoma is related to the granulation tissue around the initial haematoma. During the absorption of a haematoma, granulation tissues form around it, which can be seen on contrast CT as ringenhancement [172]. The granulation tissue is capsule-like which limits the absorption of haematomas. Subsequently, the oncotic pressure inside the haematoma increases and the infiltration of plasma increases the tension inside the capsule progressively [162]. Additionally, blood may leak 

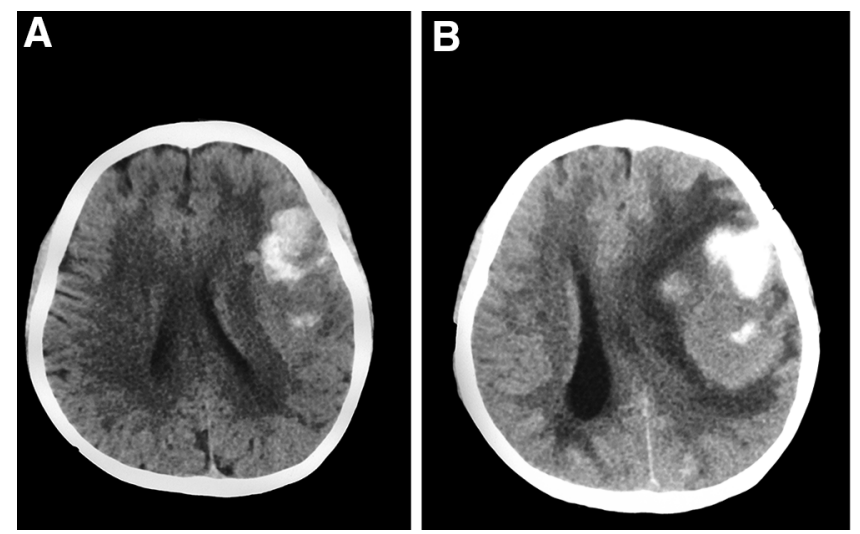

Fig. 4 A case of subacute progressing stroke. The patient was admitted to our hospital because of dysphagia, hemiparalysis, and conscious disturbance. a CT on hospital admission showed left parietal and frontal intracerebral haemorrhage. After the initial treatment, the patient regained consciousness. b 10 days after hospital admission, the patient became lethargic, and repeated CT showed an increased mass effect and midline shift, with enlargement of the

from the abundant capillaries contained in the granulation tissue repeatedly. Thus, this severely increased tension inside the initial haematoma cavity contributes to rapidly increasing ICP and deterioration of clinical conditions [105].

\section{Managements}

\section{Osmotherapy}

When a sudden deterioration of clinical signs and symptoms occur during the conservative treatment process, a subacute progression of ICH should be suspected. A repeated CT at this time is necessary to determine whether there is increased mass effect or re-bleeding. The priority is to control the ICP, and a more intensive osmotherapy should be applied. Placement of an ICP monitor is recommended, especially in patients with a Glasgow Coma Scale score of less than eight and those with transtentorial herniation [122]. Several researchers have recommended an early and continuous infusion of hypertonic saline to reduce the impending perihaematomal oedema and progression of mass effect [167]. However, osmotherapy might not be beneficial for certain patients; therefore, surgery would be the best recommendation for these patients.

\section{Surgeries}

As previously described, minimally invasive surgery is more applicable in reducing the perihaematomal oedema progression [124]. For the patients with tension
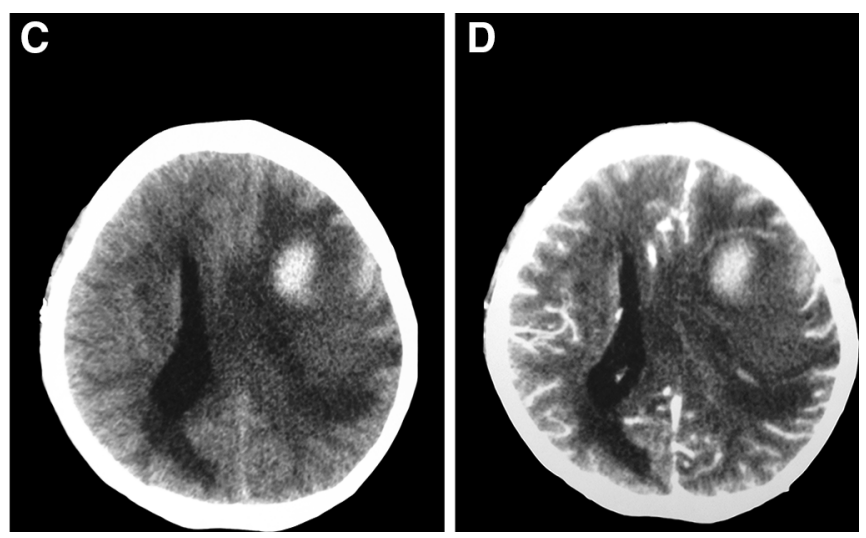

perihaematomal oedema. Stronger osmotic therapy was applied immediately and the patient's consciousness improved. c Repeated CT at 17 days post hospital admission showed that the initial haematoma shrank further, the density of the brain oedema decreased, and the mass effect alleviated modestly. d An enhanced CT at 17 days showed no ring-enhancement, eliminating the tension haematoma

haematoma, surgery is the only way to relieve the severely increased tension inside the haematoma [105]. If the hyperosmolar therapy was ineffective, a tension haematoma should be suspected. Once CT or MRI confirms the presence of a tension haematoma and markedly increased the mass effect, surgery is needed immediately to rescue the patient from rapidly increasing intracranial pressure. Such patients may benefit from stereotactic aspiration due to the highly increased tension inside the haematoma cavity [75, 105] (Fig. 5).

\section{Chronic progressing haemorrhagic stroke: chronic encapsulated intracerebral haematoma}

\section{Clinical features}

Chronic encapsulated intracerebral haematoma or chronic expanding intracerebral haematoma (CEICH) was first described by Hirsh in 1981 [69]; although it has been known for a long time, its causes and mechanisms have not been established. Different from spontaneous ICH, CEICH is characterised by a slow and gradual onset. The symptoms often evolve and appear within weeks or months, including seizures, progressive neurological deficit, such as mental disturbance, ataxia, hemianopia or hemiparesis, symptoms of increased intracranial pressure such as nausea, vomiting, headache, and papilloedema [108, 133, 147].

Neuroimaging strategies help to diagnose CEICH. The characteristic CT findings are round or similar round lesion with variable density, with or without calcification [28], and usually produce significant perilesional oedema and 
Fig. 5 Management of subacute progressing stroke

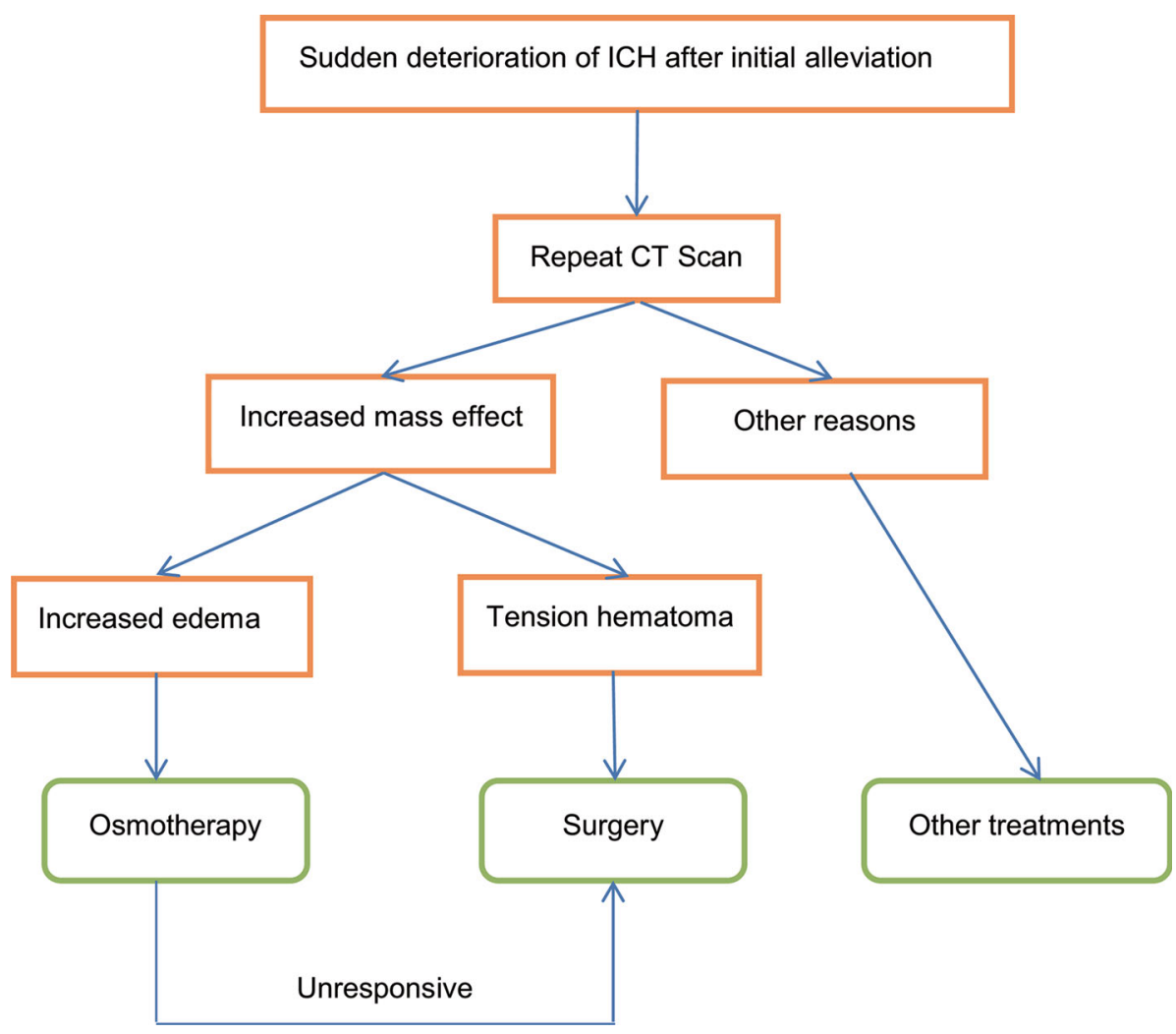

mass effect [25, 133, 147, 181]. Therefore, CEICH resembles an intracranial tumour or brain abscess and was initially easily misdiagnosed as those two [143, 181]. Characteristic MRI findings include: high-signal lesions indicating chronic haemorrhage with mixed-signal, which indicates recent haemorrhage on both $\mathrm{T} 1$ and $\mathrm{T} 2$ weighed images; low-signal surroundings on T2 images suggesting a fibrous encapsulation around the lesion [181]. Digital subtraction angiography is useful in detecting some of the underlying causes of CEICH [92, 127].

\section{Causes}

For the encapsulated haematoma or $\mathrm{CEICH}$, occult vascular malformations are often the underlying cause. Arteriovenous malformations [133], cavernomas [64, 120], microaneurysms, vascular amyloidosis or atherosclerosis are the common underlying causes [108, 133, 147]. CEICH also occurs after radiosurgeries [92] or trauma [25, 181]. Several causes remain unknown [147].

Whether hypertension contributes to the causes of $\mathrm{CEICH}$ is controversial. Most of the cases reported do not have a history of hypertension [64, 120], whereas several cases have been reported to be likely caused by hypertension [102]. Liquified chronic intracerebral haematomas is often secondary to hypertension [179] (Table 2).
Table 2 Causes of $\mathrm{CEICH}$

\begin{tabular}{ll}
\hline Etiology & References \\
\hline Hypertension & Yashon et al. [179] \\
Lin et al. [102] \\
Arteriovenous malformation & Hirsh et al. [69] \\
& Pozzati et al. [133] \\
& Sakaida et al. [147] \\
Cavernoma & Masuzawa et al. [108] \\
& Monma et al. [120] \\
& Greiner-Perth et al. [64] \\
Radiosurgery & Kurita et al. [92] \\
& Lee et al. [96] \\
& Nakamizo et al. [127] \\
& Foroughi et al. [49] \\
Trauma & Yuguang et al. [181] \\
Unknown & Cakir et al. [25] \\
& Pozzati et al. [133] \\
& Fiumara et al. [44] \\
\hline
\end{tabular}

Mechanisms

The mechanism of the progression of $\mathrm{CEICH}$ has not been established, and it is hard to predict whether $\mathrm{CEICH}$ will affect certain patients. On histological examination, $\mathrm{CEICH}$ consists of central haematoma and peripheral thick 
Fig. 6 Mechanisms of $\mathrm{CEICH}$

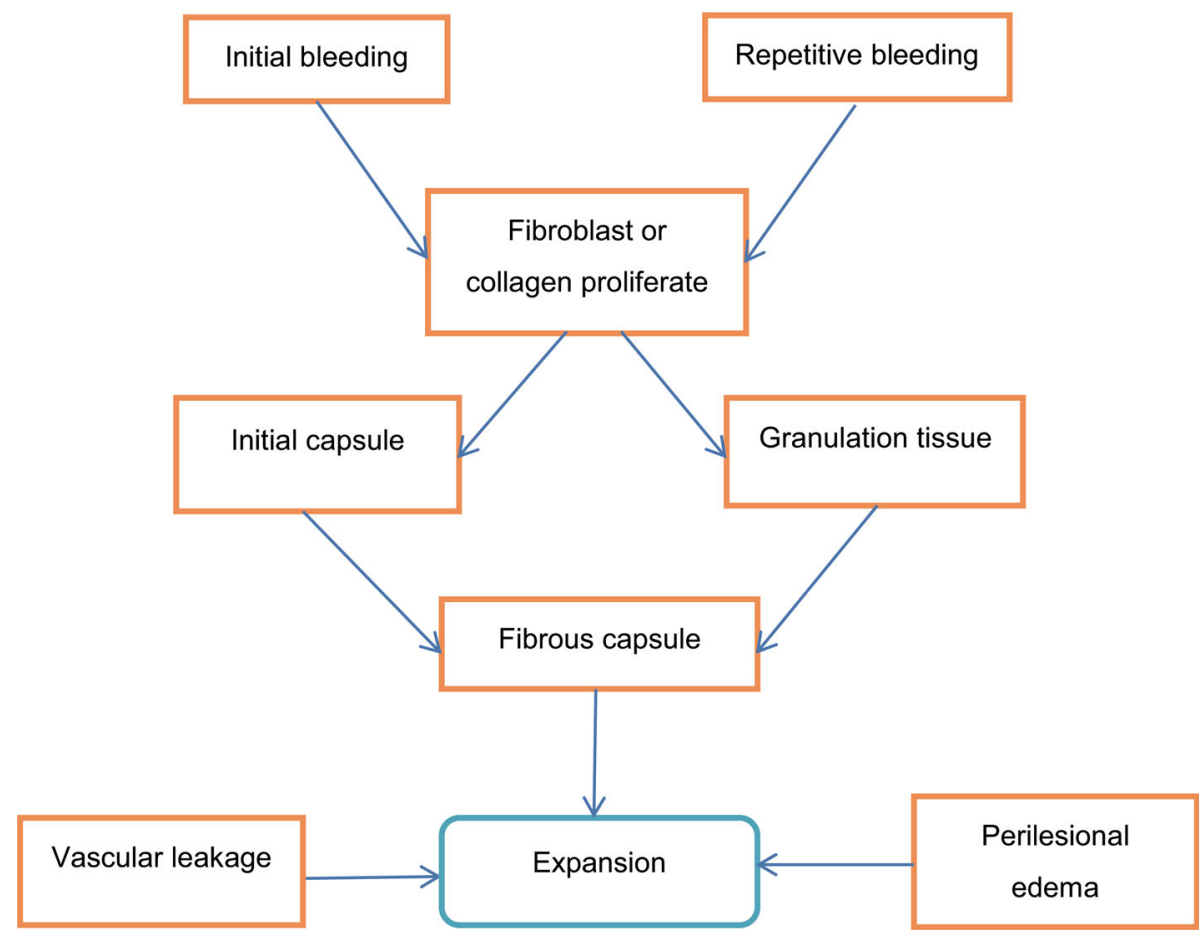

capsule. The haematoma often contains abundant blood clots at varied stages of development, hemosiderin-laden macrophages, cholesterol clefts, calcifications, fibrous tissue, and can present with or without arteriovenous malformations [102]. The capsule is composed of a thick outer membrane of dense collagen fibres and an inner thin granulation tissue rich in capillary [120, 127]. Researchers believed that some of the initial bleeding could stimulate a reactive response in the peripheral cerebral tissue and promote arachnoid fibroblast or collagen tissue to proliferate, forming the initial capsule membrane [44]; the subsequent repetitive bleeding or exudation produces granulation tissue and promotes the fibroblastic reaction to develop into a fibrous capsule [102, 181]. The blood elements leak into the cavity, causing the haematoma to expand [102].

In those patients without obvious vascular malformation in their histological examination, occult cerebrovascular malformations might account for the initial haemorrhage, which might be destroyed in the haemorrhagic episode [102, 143]. Pozzati et al. believes that the 'self-destroying' nature of the cerebral malformation primarily contributes to the formation of CEICH [133].

As for the radiosurgery, repetitive minor bleeding within the radionecrotic brain tissue most likely may initiate the formation of CEICH [49, 92, 96]. Nakamizo et al. [127] believes that radiosurgery could impose hypoxic stress on the surrounding brain tissue and induce a transcription of vascular endothelial growth factor, which could contribute to the abnormal angiogenesis and vascular leakage that expand the haematoma (Fig. 6).

\section{Managements of $\mathrm{CEICH}$}

Although spontaneous regression has been reported [64], most researchers recommend surgery for treating $\mathrm{CEICH}$ [127]. Because the recurrent bleeding of the capsule and abnormal vessels are the primary cause of the progression of $\mathrm{CEICH}$, the capsule and hidden vessel malformation should also be evacuated as much as possible, as much as the haematoma itself, to avoid relapse and re-bleeding [181]. The entire lesion and the adjacent brain tissue should be carefully examined to rule out potential vascular malformation [64]. The prognosis of $\mathrm{CEICH}$ after surgery is usually good; however, patients could die from recurrent bleeding [133].

\section{Conclusions and future directions}

In conclusion, we have proposed the concept of progressing haemorrhagic stroke, and we explored several aspects of its categories, causes, mechanisms and management. Despite tremendous efforts in this field, early deterioration and death are serious problems in patients with spontaneous intracerebral haemorrhage. Although some work has been conducted or is being performed to test the effectiveness of possible treatments, additional exploration of 
the mechanisms underlying the early deterioration is required. Furthermore, because of the special second oedema peak in ICH, subacute haemorrhagic stroke is specific in haemorrhagic stroke. However, subacute haemorrhagic stroke has rarely been reported or explored, although it is an important clinical entity that deserves concern. The causes and mechanisms are not very well understood, and the standard treatments need to be established. Chronic encapsulated intracerebral haemorrhage has gained increasing attention not only because of the more frequent recognition but also because of the prevalence of radiosurgery application in treating neurological diseases. More effective ways to predict and prevent the occurrence of CEICH are warranted.

\section{Search strategy and selection criteria}

We searched PubMed, China National Knowledge Infrastructure (CNKI) and the Cochrane Library. We also searched the reference lists of retrieved articles, and we cross-referenced. Search terms included "progressing stroke", "progressive stroke", "stroke-in-evolution", "h(a)emorrhagic stroke", "cerebral h(a)emorrhage", "intracerebral h(a)emorrhage", "spontaneous intracerebral h(a)emorrhage", "early neurological deterioration", "secondary neurological deterioration", "chronic encapsulated intracerebral h(a)emorrhage", "h(a)ematoma expansion", "perih(a)ematomal (o)edema", "intraventricular h(a)emorrhage", "tension h(a)ematoma", "inflammation", "treatment", and "management". The search included both human and animal studies. Papers published in both English and Chinese from 1971 to 2013 were reviewed. Articles were selected on the basis of relevance to the topics covered in the Review. Where issues are controversial, evidence on both sides of the issue is given.

Acknowledgments This work was supported by the National key disciplines establishing foundation from Chinese National Institution of Health.

Conflicts of interest We have no conflicts of interest.

Open Access This article is distributed under the terms of the Creative Commons Attribution License which permits any use, distribution, and reproduction in any medium, provided the original author(s) and the source are credited.

\section{References}

1. Tranexamic acid for Intracerebral haemorrhage TICH-2: a pragmatic phase III prospective double blind randomised placebo controlled trial. doi: 10.1186/ISRCTN93732214. http:// www.controlled-trials.com/ISRCTN93732214/tranexamic+acid. Accessed 2 Feb 2014
2. Agnihotri S, Czap A, Staff I, Fortunato G, McCullough LD (2011) Peripheral leukocyte counts and outcomes after intracerebral hemorrhage. J Neuroinflammation 8:160

3. Aguilar MI, Freeman WD (2010) Treatment of coagulopathy in intracranial hemorrhage. Curr Treat Options Neurol 12:113-128

4. Aguilar MI, Hart RG, Kase CS, Freeman WD, Hoeben BJ, Garcia RC, Ansell JE, Mayer SA, Norrving B, Rosand J, Steiner T, Wijdicks EF, Yamaguchi T, Yasaka M (2007) Treatment of warfarin-associated intracerebral hemorrhage: literature review and expert opinion. Mayo Clin Proc Mayo Clin 82:82-92

5. Aiyagari V, Testai FD (2009) Correction of coagulopathy in warfarin associated cerebral hemorrhage. Curr Opin Crit Care 15:87-92

6. Al-Shahi Salman R (2009) Haemostatic drug therapies for acute spontaneous intracerebral haemorrhage. Cochrane Database Syst Rev (4):CD005951

7. Anderson CS, Heeley E, Huang Y, Wang J, Stapf C, Delcourt C, Lindley R, Robinson T, Lavados P, Neal B, Hata J, Arima H, Parsons M, Li Y, Wang J, Heritier S, Li Q, Woodward M, Simes RJ, Davis SM, Chalmers J, Investigators I (2013) Rapid bloodpressure lowering in patients with acute intracerebral hemorrhage. N Engl J Med 368:2355-2365

8. Anderson CS, Huang Y, Arima H, Heeley E, Skulina C, Parsons MW, Peng B, Li Q, Su S, Tao QL, Li YC, Jiang JD, Tai LW, Zhang JL, Xu E, Cheng Y, Morgenstern LB, Chalmers J, Wang JG, Investigators I (2010) Effects of early intensive blood pressure-lowering treatment on the growth of hematoma and perihematomal edema in acute intracerebral hemorrhage: the Intensive Blood Pressure Reduction in Acute Cerebral Haemorrhage Trial (INTERACT). Stroke; J Cereb Circ 41:307-312

9. Appelboom G, Piazza MA, Hwang BY, Carpenter A, Bruce SS, Mayer S, Connolly ES Jr (2011) Severity of intraventricular extension correlates with level of admission glucose after intracerebral hemorrhage. Stroke; J Cereb Circ 42:1883-1888

10. Babu R, Bagley JH, Di C, Friedman AH, Adamson C (2012) Thrombin and hemin as central factors in the mechanisms of intracerebral hemorrhage-induced secondary brain injury and as potential targets for intervention. Neurosurg Focus 32:E8

11. Balami JS, Buchan AM (2012) Complications of intracerebral haemorrhage. Lancet Neurol 11:101-118

12. Barras CD, Tress BM, Christensen S, Collins M, Desmond PM, Skolnick BE, Mayer SA, Davis SM, Recombinant Activated Factor VIIIHTI (2013) Quantitative CT densitometry for predicting intracerebral hemorrhage growth. AJNR Am J Neuroradiol 34:1139-1144

13. Barras CD, Tress BM, Christensen S, MacGregor L, Collins M, Desmond PM, Skolnick BE, Mayer SA, Broderick JP, Diringer MN, Steiner T, Davis SM (2009) Density and shape as CT predictors of intracerebral hemorrhage growth. Stroke; J Cereb Circ 40:1325-1331

14. Bejot Y, Aboa-Eboule C, Hervieu M, Jacquin A, Osseby GV, Rouaud O, Giroud M (2012) The deleterious effect of admission hyperglycemia on survival and functional outcome in patients with intracerebral hemorrhage. Stroke; J Cereb Circ 43:243-245

15. Bereczki D, Fekete I, Prado GF, Liu M (2007) Mannitol for acute stroke. Cochrane Database Syst Rev (3):CD001153

16. Bhattathiri PS, Gregson B, Prasad KS, Mendelow AD, Investigators S (2006) Intraventricular hemorrhage and hydrocephalus after spontaneous intracerebral hemorrhage: results from the STICH trial. Acta Neurochir Suppl 96:65-68

17. Biffi A, Battey TW, Ayres AM, Cortellini L, Schwab K, Gilson AJ, Rost NS, Viswanathan A, Goldstein JN, Greenberg SM, Rosand J (2011) Warfarin-related intraventricular hemorrhage: imaging and outcome. Neurology 77:1840-1846 
18. Birschel P, Ellul J, Barer D (2004) Progressing stroke: towards an internationally agreed definition. Cerebrovasc Dis 17:242-252

19. Broderick JP, Diringer MN, Hill MD, Brun NC, Mayer SA, Steiner T, Skolnick BE, Davis SM, Recombinant Activated Factor VIIIHTI (2007) Determinants of intracerebral hemorrhage growth: an exploratory analysis. Stroke; J Cereb Circ 38:1072-1075

20. Brott T, Broderick J, Kothari R, Barsan W, Tomsick T, Sauerbeck L, Spilker J, Duldner J, Khoury J (1997) Early hemorrhage growth in patients with intracerebral hemorrhage. Stroke; J Cereb Circ 28:1-5

21. Brouwers HB, Goldstein JN, Romero JM, Rosand J (2012) Clinical applications of the computed tomography angiography spot sign in acute intracerebral hemorrhage: a review. Stroke; J Cereb Circ 43:3427-3432

22. Brunswick AS, Hwang BY, Appelboom G, Hwang RY, Piazza MA, Connolly ES Jr (2012) Serum biomarkers of spontaneous intracerebral hemorrhage induced secondary brain injury. J Neurol Sci 321:1-10

23. Butcher KS, Baird T, MacGregor L, Desmond P, Tress B, Davis S (2004) Perihematomal edema in primary intracerebral hemorrhage is plasma derived. Stroke; J Cereb Circ 35:1879-1885

24. Cabral KP, Fraser GL, Duprey J, Gibbons BA, Hayes T, Florman JE, Seder DB (2013) Prothrombin complex concentrates to reverse warfarin-induced coagulopathy in patients with intracranial bleeding. Clin Neurol Neurosurg 115:770-774

25. Cakir E, Kuzeyli K, Usul H, Sayin OC, Kararslan G, Peksoylu B (2006) Ruptured chronic encapsulated intracerebral hematoma in infancy: review of the literature with a case report. Child's Nerv Syst: ChNS : Off J Int Soc Pediatr Neurosurg 22:436-439

26. Carhuapoma JR, Hanley DF, Banerjee M, Beauchamp NJ (2003) Brain edema after human cerebral hemorrhage: a magnetic resonance imaging volumetric analysis. J Neurosurg Anesthesiol $15: 230-233$

27. Castillo J (1999) Deteriorating stroke: diagnostic criteria, predictors, mechanisms and treatment. Cerebrovasc Dis 9(Suppl 3): $1-8$

28. Chen NF, Wang YC, Shen CC, Jan YJ, Chen WH, Leu CH (2004) Calcification and ossification of chronic encapsulated intracerebral haematoma: case report. J Clin Neurosci: Official J Neurosurg Soc Australas 11:527-530

29. Cosolo WC, Martinello P, Louis WJ, Christophidis N (1989) Blood-brain barrier disruption using mannitol: time course and electron microscopy studies. Am J Physiol 256:R443-R447

30. Davis SM, Broderick J, Hennerici M, Brun NC, Diringer MN, Mayer SA, Begtrup K, Steiner T (2006) Hematoma growth is a determinant of mortality and poor outcome after intracerebral hemorrhage. Neurology 66:1175-1181

31. de Lecinana MA, Huertas N, Egido JA, Muriel A, Garcia A, Ruiz-Ares G, Diez-Tejedor E, Fuentes B (2013) Questionable reversal of anticoagulation in the therapeutic management of cerebral haemorrhage associated with vitamin $\mathrm{K}$ antagonists. Thromb Haemost 110:1145-1151

32. Delcourt C, Huang Y, Arima H, Chalmers J, Davis SM, Heeley EL, Wang J, Parsons MW, Liu G, Anderson CS, Investigators I (2012) Hematoma growth and outcomes in intracerebral hemorrhage: the INTERACT1 study. Neurology 79:314-319

33. Delgado Almandoz JE, Yoo AJ, Stone MJ, Schaefer PW, Goldstein JN, Rosand J, Oleinik A, Lev MH, Gonzalez RG, Romero JM (2009) Systematic characterization of the computed tomography angiography spot sign in primary intracerebral hemorrhage identifies patients at highest risk for hematoma expansion: the spot sign score. Stroke; J Cereb Circ 40:2994-3000

34. Delgado Almandoz JE, Yoo AJ, Stone MJ, Schaefer PW, Oleinik A, Brouwers HB, Goldstein JN, Rosand J, Lev MH,
Gonzalez RG, Romero JM (2010) The spot sign score in primary intracerebral hemorrhage identifies patients at highest risk of inhospital mortality and poor outcome among survivors. Stroke; J Cereb Circ 41:54-60

35. Demchuk AM, Dowlatshahi D, Rodriguez-Luna D, Molina CA, Blas YS, Dzialowski I, Kobayashi A, Boulanger JM, Lum C, Gubitz G, Padma V, Roy J, Kase CS, Kosior J, Bhatia R, Tymchuk S, Subramaniam S, Gladstone DJ, Hill MD, Aviv RI, Group PRSICs (2012) Prediction of haematoma growth and outcome in patients with intracerebral haemorrhage using the CT-angiography spot sign (PREDICT): a prospective observational study. Lancet Neurol 11:307-314

36. Di Napoli M, Godoy DA, Campi V, del Valle M, Pinero G, Mirofsky M, Popa-Wagner A, Masotti L, Papa F, Rabinstein AA (2011) C-reactive protein level measurement improves mortality prediction when added to the spontaneous intracerebral hemorrhage score. Stroke; J Cereb Circ 42:1230-1236

37. Diringer MN, Edwards DF (2001) Admission to a neurologic/ neurosurgical intensive care unit is associated with reduced mortality rate after intracerebral hemorrhage. Crit Care Med 29:635-640

38. Donovan FM, Pike CJ, Cotman CW, Cunningham DD (1997) Thrombin induces apoptosis in cultured neurons and astrocytes via a pathway requiring tyrosine kinase and RhoA activities. J Neurosci: Off J Soc Neurosci 17:5316-5326

39. Dowlatshahi D, Smith EE, Flaherty ML, Ali M, Lyden P, Demchuk AM, Collaborators V (2011) Small intracerebral haemorrhages are associated with less haematoma expansion and better outcomes. Int $\mathrm{J}$ Stroke: Off $\mathrm{J}$ Int Stroke Soc 6:201-206

40. Ederies A, Demchuk A, Chia T, Gladstone DJ, Dowlatshahi D, Bendavit G, Wong K, Symons SP, Aviv RI (2009) Postcontrast CT extravasation is associated with hematoma expansion in CTA spot negative patients. Stroke; J Cereb Circ 40:1672-1676

41. European Stroke Initiative Writing C, Writing Committee for the EEC, Steiner T, Kaste M, Forsting M, Mendelow D, Kwiecinski H, Szikora I, Juvela S, Marchel A, Chapot R, Cognard C, Unterberg A, Hacke W (2006) Recommendations for the management of intracranial haemorrhage - part I: spontaneous intracerebral haemorrhage. The European Stroke Initiative Writing Committee and the Writing Committee for the EUSI Executive Committee. Cerebrovasc Dis 22:294-316

42. Fernandes HM, Gregson B, Siddique S, Mendelow AD (2000) Surgery in intracerebral hemorrhage. The uncertainty continues. Stroke; J Cereb Circ 31:2511-2516

43. Fisher CM (1971) Pathological observations in hypertensive cerebral hemorrhage. J Neuropathol Exp Neurol 30:536-550

44. Fiumara E, Gambacorta M, D'Angelo V, Ferrara M, Corona C (1989) Chronic encapsulated intracerebral haematoma: pathogenetic and diagnostic considerations. J Neurol Neurosurg Psychiatry 52:1296-1299

45. Flaherty ML, Kissela B, Woo D, Kleindorfer D, Alwell K, Sekar P, Moomaw CJ, Haverbusch M, Broderick JP (2007) The increasing incidence of anticoagulant-associated intracerebral hemorrhage. Neurology 68:116-121

46. Flemming KD, Wijdicks EF, Louis EK, Li H (1999) Predicting deterioration in patients with lobar haemorrhages. J Neurol Neurosurg Psychiatry 66:600-605

47. Flibotte JJ, Hagan N, O'Donnell J, Greenberg SM, Rosand J (2004) Warfarin, hematoma expansion, and outcome of intracerebral hemorrhage. Neurology 63:1059-1064

48. Florczak-Rzepka M, Grond-Ginsbach C, Montaner J, Steiner T (2012) Matrix metalloproteinases in human spontaneous intracerebral hemorrhage: an update. Cerebrovasc Dis 34:249-262

49. Foroughi M, Kemeny AA, Lehecka M, Wons J, Kajdi L, Hatfield R, Marks S (2010) Operative intervention for delayed 
symptomatic radionecrotic masses developing following stereotactic radiosurgery for cerebral arteriovenous malformationscase analysis and literature review. Acta Neurochir (Wien) 152:803-815

50. Fujii Y, Takeuchi S, Sasaki O, Minakawa T, Tanaka R (1998) Multivariate analysis of predictors of hematoma enlargement in spontaneous intracerebral hemorrhage. Stroke; J Cereb Circ 29:1160-1166

51. Fujii Y, Tanaka R, Takeuchi S, Koike T, Minakawa T, Sasaki O (1994) Hematoma enlargement in spontaneous intracerebral hemorrhage. J Neurosurg 80:51-57

52. Fulesdi B, Kovacs KR, Bereczki D, Bagyi P, Fekete I, Csiba L (2013) Computed tomography and transcranial doppler findings in acute and subacute phases of intracerebral hemorrhagic stroke. J Neuroimaging: Off J Am Soc Neuroimaging. doi:10. 1111/j.1552-6569.2012.00776.x

53. Fung C, Murek M, Z'Graggen WJ, Krahenbuhl AK, Gautschi OP, Schucht P, Gralla J, Schaller K, Arnold M, Fischer U, Mattle HP, Raabe A, Beck J (2012) Decompressive hemicraniectomy in patients with supratentorial intracerebral hemorrhage. Stroke; J Cereb Circ 43:3207-3211

54. Gautier JC (1985) Stroke-in-progression. Stroke; J Cereb Circ 16:729-733

55. Gebel JM, Brott TG, Sila CA, Tomsick TA, Jauch E, Salisbury S, Khoury J, Miller R, Pancioli A, Duldner JE, Topol EJ, Broderick JP (2000) Decreased perihematomal edema in thrombolysis-related intracerebral hemorrhage compared with spontaneous intracerebral hemorrhage. Stroke; J Cereb Circ 31:596-600

56. Gebel JM Jr, Jauch EC, Brott TG, Khoury J, Sauerbeck L, Salisbury S, Spilker J, Tomsick TA, Duldner J, Broderick JP (2002) Natural history of perihematomal edema in patients with hyperacute spontaneous intracerebral hemorrhage. Stroke; J Cereb Circ 33:2631-2635

57. Gingrich MB, Junge CE, Lyuboslavsky P, Traynelis SF (2000) Potentiation of NMDA receptor function by the serine protease thrombin. J Neurosci: Off J Soc Neurosci 20:4582-4595

58. Godoy DA, Pinero GR, Svampa S, Papa F, Di Napoli M (2008) Hyperglycemia and short-term outcome in patients with spontaneous intracerebral hemorrhage. Neurocrit Care 9:217-229

59. Goldstein J, Brouwers H, Romero J, McNamara K, Schwab K, Greenberg S, Rosand J (2012) SCORE-IT: the Spot Sign score in restricting ICH growth horizontal line an Atach-II ancillary study. J Vasc Interv Neurol 5:20-25

60. Goldstein JN, Thomas SH, Frontiero V, Joseph A, Engel C, Snider R, Smith EE, Greenberg SM, Rosand J (2006) Timing of fresh frozen plasma administration and rapid correction of coagulopathy in warfarin-related intracerebral hemorrhage. Stroke; J Cereb Circ 37:151-155

61. Gong Y, Xi GH, Keep RF, Hoff JT, Hua Y (2005) Complement inhibition attenuates brain edema and neurological deficits induced by thrombin. Acta Neurochir Suppl 95:389-392

62. Gray CS, Hildreth AJ, Sandercock PA, O'Connell JE, Johnston DE, Cartlidge NE, Bamford JM, James OF, Alberti KG, Collaboration GT (2007) Glucose-potassium-insulin infusions in the management of post-stroke hyperglycaemia: the UK Glucose Insulin in Stroke Trial (GIST-UK). Lancet Neurol 6:397-406

63. Gregson BA, Broderick JP, Auer LM, Batjer H, Chen XC, Juvela S, Morgenstern LB, Pantazis GC, Teernstra OP, Wang WZ, Zuccarello M, Mendelow AD (2012) Individual patient data subgroup meta-analysis of surgery for spontaneous supratentorial intracerebral hemorrhage. Stroke; J Cereb Circ 43:1496-1504

64. Greiner-Perth R, Neubauer U, Schenke H (1997) Chronic encapsulated intracerebral hematoma-a well-defined disease. Report on two cases and review of the literature. Neurosurg Rev 20:231-238
65. Hallevi H, Abraham AT, Barreto AD, Grotta JC, Savitz SI (2010) The spot sign in intracerebral hemorrhage: the importance of looking for contrast extravasation. Cerebrovasc Dis 29:217-220

66. Hallevi H, Albright KC, Aronowski J, Barreto AD, MartinSchild S, Khaja AM, Gonzales NR, Illoh K, Noser EA, Grotta JC (2008) Intraventricular hemorrhage: anatomic relationships and clinical implications. Neurology 70:848-852

67. Hanley DF (2009) Intraventricular hemorrhage: severity factor and treatment target in spontaneous intracerebral hemorrhage. Stroke; J Cereb Circ 40:1533-1538

68. Herrick DB, Ziai WC, Thompson CB, Lane K, McBee NA, Hanley DF (2011) Systemic hematologic status following intraventricular recombinant tissue-type plasminogen activator for intraventricular hemorrhage: the CLEAR IVH Study Group. Stroke; J Cereb Circ 42:3631-3633

69. Hirsh LF, Spector HB, Bogdanoff BM (1981) Chronic encapsulated intracerebral hematoma. Neurosurgery 9:169-172

70. Ho CL, Ang CB, Lee KK, Ng IH (2008) Effects of glycaemic control on cerebral neurochemistry in primary intracerebral haemorrhage. J Clin Neurosci: Off J Neurosurg Soc Australas $15: 428-433$

71. Hu S, Xi G, Jin H, He Y, Keep RF, Hua Y (2011) Thrombininduced autophagy: a potential role in intracerebral hemorrhage. Brain Res 1424:60-66

72. Hua Y, Keep RF, Hoff JT, Xi G (2007) Brain injury after intracerebral hemorrhage: the role of thrombin and iron. Stroke; J Cereb Circ 38:759-762

73. Hua Y, Wu J, Keep RF, Nakamura T, Hoff JT, Xi G (2006) Tumor necrosis factor-alpha increases in the brain after intracerebral hemorrhage and thrombin stimulation. Neurosurgery 58:542-550 (discussion 542-550)

74. Huang FP, Xi G, Keep RF, Hua Y, Nemoianu A, Hoff JT (2002) Brain edema after experimental intracerebral hemorrhage: role of hemoglobin degradation products. J Neurosurg 96:287-293

75. Huang H, Liu Z, Kang G, Li S, Tian Z (1996) Diagnosis and treatment of hypertensive tension hematoma. Med J Chin PLA 21:2

76. Huhtakangas J, Tetri S, Juvela S, Saloheimo P, Bode MK, Karttunen V, Karajamaki A, Hillbom M (2012) Improved survival of patients with warfarin-associated intracerebral haemorrhage: a retrospective longitudinal population-based study. Int J Stroke: Off J Int Stroke Soc. doi:10.1111/j.1747-4949.2012. 00926.x

77. Huttner HB, Schellinger PD, Hartmann M, Kohrmann M, Juettler E, Wikner J, Mueller S, Meyding-Lamade U, Strobl R, Mansmann U, Schwab S, Steiner T (2006) Hematoma growth and outcome in treated neurocritical care patients with intracerebral hemorrhage related to oral anticoagulant therapy: comparison of acute treatment strategies using vitamin $\mathrm{K}$, fresh frozen plasma, and prothrombin complex concentrates. Stroke; J Cereb Circ 37:1465-1470

78. Ikram MA, Wieberdink RG, Koudstaal PJ (2012) International epidemiology of intracerebral hemorrhage. Curr Atheroscler Rep 14:300-306

79. Inaji M, Tomita H, Tone O, Tamaki M, Suzuki R, Ohno K (2003) Chronological changes of perihematomal edema of human intracerebral hematoma. Acta Neurochir Suppl $86: 445-448$

80. Intercollegiate Stroke Working Party (2012) National clinical guideline for stroke. Royal College of Physicians, London

81. Ji N, Lu JJ, Zhao YL, Wang S, Zhao JZ (2009) Imaging and clinical prognostic indicators for early hematoma enlargement after spontaneous intracerebral hemorrhage. Neurol Res 31:362-366

82. Jiang Y, Wu J, Hua Y, Keep RF, Xiang J, Hoff JT, Xi G (2002) Thrombin-receptor activation and thrombin-induced brain 
tolerance. J Cereb Blood Flow Metab: Off J Int Soc Cereb Blood Flow Metab 22:404-410

83. Jorgensen HS, Nakayama H, Raaschou HO, Olsen TS (1994) Effect of blood pressure and diabetes on stroke in progression. Lancet 344:156-159

84. Karepov VG, Gur AY, Bova I, Aronovich BD, Bornstein NM (2006) Stroke-in-evolution: infarct-inherent mechanisms versus systemic causes. Cerebrovasc Dis 21:42-46

85. Kaufmann AM, Cardoso ER (1992) Aggravation of vasogenic cerebral edema by multiple-dose mannitol. J Neurosurg 77:584-589

86. Kawakita K, Kawai N, Kuroda Y, Yasashita S, Nagao S (2006) Expression of matrix metalloproteinase- 9 in thrombin-induced brain edema formation in rats. J Stroke Cerebrovasc Dis: Off J Natl Stroke Assoc 15:88-95

87. Kazui S, Minematsu K, Yamamoto H, Sawada T, Yamaguchi T (1997) Predisposing factors to enlargement of spontaneous intracerebral hematoma. Stroke; J Cereb Circ 28:2370-2375

88. Kazui S, Naritomi H, Yamamoto H, Sawada T, Yamaguchi T (1996) Enlargement of spontaneous intracerebral hemorrhage. Incidence and time course. Stroke; J Cereb Circ 27:1783-1787

89. Kimura K, Iguchi Y, Inoue T, Shibazaki K, Matsumoto N, Kobayashi K, Yamashita S (2007) Hyperglycemia independently increases the risk of early death in acute spontaneous intracerebral hemorrhage. J Neurol Sci 255:90-94

90. Koch S, Romano JG, Forteza AM, Otero CM, Rabinstein AA (2008) Rapid blood pressure reduction in acute intracerebral hemorrhage: feasibility and safety. Neurocrit Care 8:316-321

91. Koenig MA, Bryan M, Lewin JL 3rd, Mirski MA, Geocadin RG, Stevens RD (2008) Reversal of transtentorial herniation with hypertonic saline. Neurology 70:1023-1029

92. Kurita H, Sasaki T, Kawamoto S, Taniguchi M, Kitanaka C, Nakaguchi H, Kirino T (1996) Chronic encapsulated expanding hematoma in association with gamma knife stereotactic radiosurgery for a cerebral arteriovenous malformation. Case report. J Neurosurg 84:874-878

93. Kwan J, Hand P (2006) Early neurological deterioration in acute stroke: clinical characteristics and impact on outcome. QJM: Mon J Assoc Physicians 99:625-633

94. Langhorne P, Fearon P, Ronning OM, Kaste M, Palomaki H, Vemmos K, Kalra L, Indredavik B, Blomstrand C, Rodgers H, Dennis MS, Al-Shahi Salman R, Stroke Unit Trialists C (2013) Stroke unit care benefits patients with intracerebral hemorrhage: systematic review and meta-analysis. Stroke; J Cereb Circ 44:3044-3049

95. Lauer A, Pfeilschifter W, Schaffer CB, Lo EH, Foerch C (2013) Intracerebral haemorrhage associated with antithrombotic treatment: translational insights from experimental studies. Lancet Neurol 12:394-405

96. Lee CC, Pan DH, Ho DM, Wu HM, Chung WY, Liu KD, Guo WY, Shih YH (2011) Chronic encapsulated expanding hematoma after gamma knife stereotactic radiosurgery for cerebral arteriovenous malformation. Clin Neurol Neurosurg 113:668-671

97. Lee JY, King C, Stradling D, Warren M, Nguyen D, Lee J, Riola MA, Montoya R, Patel D, Le VH, Welbourne SJ, Cramer SC (2012) Influence of hematoma location on acute mortality after intracerebral hemorrhage. J Neuroimaging: Off J Am Soc Neuroimaging. doi:10.1111/j.1552-6569.2012.00766.x

98. Lee SH, Kim BJ, Bae HJ, Lee JS, Lee J, Park BJ, Yoon BW (2010) Effects of glucose level on early and long-term mortality after intracerebral haemorrhage: the Acute Brain Bleeding Analysis Study. Diabetologia 53:429-434

99. Lee ST, Chu K, Jung KH, Kim J, Kim EH, Kim SJ, Sinn DI, Ko SY, Kim M, Roh JK (2006) Memantine reduces hematoma expansion in experimental intracerebral hemorrhage, resulting in functional improvement. J Cereb Blood Flow Metab: Off J Int Soc Cereb Blood Flow Metab 26:536-544
100. Leira R, Davalos A, Silva Y, Gil-Peralta A, Tejada J, Garcia M, Castillo J, Stroke Project CDGotSNS (2004) Early neurologic deterioration in intracerebral hemorrhage: predictors and associated factors. Neurology 63:461-467

101. Li N, Wang Y, Wang W, Ma L, Xue J, Weissenborn K, Dengler R, Worthmann H, Wang DZ, Gao P, Liu L, Wang Y, Zhao X (2011) Contrast extravasation on computed tomography angiography predicts clinical outcome in primary intracerebral hemorrhage: a prospective study of 139 cases. Stroke; J Cereb Circ 42:3441-3446

102. Lin CY, Chen Y, Tseng SH (2007) Chronic encapsulated intracerebral haematoma. J Clin Neurosci: Off J Neurosurg Soc Australas 14:58-61

103. Liu DZ, Ander BP, Xu H, Shen Y, Kaur P, Deng W, Sharp FR (2010) Blood-brain barrier breakdown and repair by Src after thrombin-induced injury. Ann Neurol 67:526-533

104. Liu J, Gao BB, Clermont AC, Blair P, Chilcote TJ, Sinha S, Flaumenhaft R, Feener EP (2011) Hyperglycemia-induced cerebral hematoma expansion is mediated by plasma kallikrein. Nat Med 17:206-210

105. Liu J, Huang Y, Wang A (2009) Diagnosis and treatment of intracerebral tension hematoma following cerebral hemorrhage. J Int Neurol Neurosurg 36:3

106. Maas MB, Nemeth AJ, Rosenberg NF, Kosteva AR, Prabhakaran S, Naidech AM (2013) Delayed intraventricular hemorrhage is common and worsens outcomes in intracerebral hemorrhage. Neurology 80:1295-1299

107. Masotti L, Di Napoli M, Godoy DA, Rafanelli D, Liumbruno G, Koumpouros N, Landini G, Pampana A, Cappelli R, Poli D, Prisco D (2011) The practical management of intracerebral hemorrhage associated with oral anticoagulant therapy. Int $\mathrm{J}$ Stroke: Off J Int Stroke Soc 6:228-240

108. Masuzawa T, Saito K, Shimabukuro H, Iwasa H, Sato F (1985) Chronic encapsulated hematomas in the brain. Acta Neuropathol 66:24-28

109. Mayer SA (2003) Ultra-early hemostatic therapy for intracerebral hemorrhage. Stroke; J Cereb Circ 34:224-229

110. Mayer SA, Brun NC, Begtrup K, Broderick J, Davis S, Diringer MN, Skolnick BE, Steiner T, Investigators FT (2008) Efficacy and safety of recombinant activated factor VII for acute intracerebral hemorrhage. N Engl J Med 358:2127-2137

111. Mayer SA, Brun NC, Begtrup K, Broderick J, Davis S, Diringer MN, Skolnick BE, Steiner T, Recombinant Activated Factor VIIIHTI (2005) Recombinant activated factor VII for acute intracerebral hemorrhage. N Engl J Med 352:777-785

112. Mayer SA, Rincon F (2005) Treatment of intracerebral haemorrhage. Lancet Neurol 4:662-672

113. Mayer SA, Sacco RL, Shi T, Mohr JP (1994) Neurologic deterioration in non comatose patients with supratentorial intracerebral hemorrhage. Neurology 44:1379-1384

114. Mendelow AD, Gregson BA, Fernandes HM, Murray GD, Teasdale GM, Hope DT, Karimi A, Shaw MD, Barer DH, Investigators S (2005) Early surgery versus initial conservative treatment in patients with spontaneous supratentorial intracerebral haematomas in the International Surgical Trial in Intracerebral Haemorrhage (STICH): a randomised trial. Lancet 365:387-397

115. Meretoja A, Churilov L, Campbell BC, Aviv RI, Yassi N, Barras C, Mitchell P, Yan B, Nandurkar H, Bladin C, Wijeratne T, Spratt NJ, Jannes J, Sturm J, Rupasinghe J, Zavala J, Lee A, Kleinig T, Markus R, Delcourt C, Mahant N, Parsons MW, Levi C, Anderson CS, Donnan GA, Davis SM (2013) The Spot sign and Tranexamic acid On Preventing ICH growth-Australasia Trial (STOP-AUST): Protocol of a phase II randomized, placebo-controlled, double-blind, multicenter trial. Int J Stroke: Off J Int Stroke Soc. doi:10.1111/ijs.12132 
116. Millikan CH, Bauer RB, Goldschmidt J (1975) A classification and outline of cerebrovascular diseases. II. Stroke; J Cereb Circ 6:564-616

117. Millikan CH, McDowell FH (1980) Treatment of progressing stroke. Prog Cardiovasc Dis 22:397-414

118. Misra UK, Kalita J, Ranjan P, Mandal SK (2005) Mannitol in intracerebral hemorrhage: a randomized controlled study. J Neurol Sci 234:41-45

119. Moller T, Hanisch UK, Ransom BR (2000) Thrombin-induced activation of cultured rodent microglia. $\mathrm{J}$ Neurochem 75:1539-1547

120. Monma S, Ohno K, Hata H, Komatsu K, Ichimura K, Hirakawa K (1990) Cavernous angioma with encapsulated intracerebral hematoma: report of two cases. Surg Neurol 34:245-249

121. Morgenstern LB, Hemphill JC 3rd, Anderson C, Becker K, Broderick JP, Connolly ES Jr, Greenberg SM, Huang JN, MacDonald RL, Messe SR, Mitchell PH, Selim M, Tamargo RJ (2010) Guidelines for the management of spontaneous intracerebral hemorrhage: a guideline for healthcare professionals from the American Heart Association/American Stroke Association. Stroke; J Cereb Circ 41:2108-2129

122. Morgenstern LB, Hemphill JC 3rd, Anderson C, Becker K, Broderick JP, Connolly ES Jr, Greenberg SM, Huang JN, MacDonald RL, Messe SR, Mitchell PH, Selim M, Tamargo RJ, American Heart Association Stroke C, Council on Cardiovascular N (2010) Guidelines for the management of spontaneous intracerebral hemorrhage: a guideline for healthcare professionals from the American Heart Association/American Stroke Association. Stroke; J Cereb Circ 41:2108-2129

123. Morioka J, Fujii M, Kato S, Fujisawa H, Akimura T, Suzuki M, Kobayashi S (2006) Surgery for spontaneous intracerebral hemorrhage has greater remedial value than conservative therapy. Surg Neurol 65:67-72 (discussion 72-63)

124. Mould WA, Carhuapoma JR, Muschelli J, Lane K, Morgan TC, McBee NA, Bistran-Hall AJ, Ullman NL, Vespa P, Martin NA, Awad I, Zuccarello M, Hanley DF, Investigators M (2013) Minimally invasive surgery plus recombinant tissue-type plasminogen activator for intracerebral hemorrhage evacuation decreases perihematomal edema. Stroke; J Cereb Circ 44:627-634

125. Naff N, Williams MA, Keyl PM, Tuhrim S, Bullock MR, Mayer SA, Coplin W, Narayan R, Haines S, Cruz-Flores S, Zuccarello M, Brock D, Awad I, Ziai WC, Marmarou A, Rhoney D, McBee N, Lane K, Hanley DF Jr (2011) Low-dose recombinant tissuetype plasminogen activator enhances clot resolution in brain hemorrhage: the intraventricular hemorrhage thrombolysis trial. Stroke; J Cereb Circ 42:3009-3016

126. Naff NJ, Hanley DF, Keyl PM, Tuhrim S, Kraut M, Bederson J, Bullock R, Mayer SA, Schmutzhard E (2004) Intraventricular thrombolysis speeds blood clot resolution: results of a pilot, prospective, randomized, double-blind, controlled trial. Neurosurgery 54:577-583 (discussion 583-574)

127. Nakamizo A, Suzuki SO, Saito N, Shono T, Matsumoto K, Onaka S, Mizoguchi M, Sasaki T (2011) Clinicopathological study on chronic encapsulated expanding hematoma associated with incompletely obliterated AVM after stereotactic radiosurgery. Acta Neurochir (Wien) 153:883-893

128. National Stroke Foundation (2010) Clinical Guidelines for Stroke Management 2010

129. Nieuwkamp DJ, de Gans K, Rinkel GJ, Algra A (2000) Treatment and outcome of severe intraventricular extension in patients with subarachnoid or intracerebral hemorrhage: a systematic review of the literature. J Neurol 247:117-121

130. Ohwaki K, Yano E, Nagashima H, Hirata M, Nakagomi T, Tamura A (2004) Blood pressure management in acute intracerebral hemorrhage: relationship between elevated blood pressure and hematoma enlargement. Stroke; J Cereb Circ 35:1364-1367

131. Piironen K, Putaala J, Rosso C, Samson Y (2012) Glucose and acute stroke: evidence for an interlude. Stroke; J Cereb Circ 43:898-902

132. Poungvarin N, Bhoopat W, Viriyavejakul A, Rodprasert P, Buranasiri P, Sukondhabhant S, Hensley MJ, Strom BL (1987) Effects of dexamethasone in primary supratentorial intracerebral hemorrhage. N Engl J Med 316:1229-1233

133. Pozzati E, Giuliani G, Gaist G, Piazza G, Vergoni G (1986) Chronic expanding intracerebral hematoma. J Neurosurg 65:611-614

134. Prasad K, Mendelow AD, Gregson B (2008) Surgery for primary supratentorial intracerebral haemorrhage. Cochrane Database Syst Rev (4):CD000200

135. Qureshi AI (2008) Acute hypertensive response in patients with stroke: pathophysiology and management. Circulation 118:176-187

136. Qureshi AI, Mendelow AD, Hanley DF (2009) Intracerebral haemorrhage. Lancet 373:1632-1644

137. Qureshi AI, Palesch YY, Martin R, Novitzke J, Cruz-Flores S, Ehtisham A, Ezzeddine MA, Goldstein JN, Hussein HM, Suri MF, Tariq N (2010) Effect of systolic blood pressure reduction on hematoma expansion, perihematomal edema, and 3-month outcome among patients with intracerebral hemorrhage: results from the antihypertensive treatment of acute cerebral hemorrhage study. Arch Neurol 67:570-576

138. Qureshi AI, Palesch YY, Martin R, Novitzke J, Cruz-Flores S, Ehtisham A, Ezzeddine MA, Goldstein JN, Kirmani JF, Hussein HM, Suri MF, Tariq N, Liu Y, Investigators A (2011) Association of serum glucose concentrations during acute hospitalization with hematoma expansion, perihematomal edema, and three month outcome among patients with intracerebral hemorrhage. Neurocrit Care 15:428-435

139. Qureshi AI, Wilson DA, Traystman RJ (1999) Treatment of elevated intracranial pressure in experimental intracerebral hemorrhage: comparison between mannitol and hypertonic saline. Neurosurgery 44:1055-1063 (discussion 1063-1054)

140. Rabinstein AA, Atkinson JL, Wijdicks EF (2002) Emergency craniotomy in patients worsening due to expanded cerebral hematoma: to what purpose? Neurology 58:1367-1372

141. Rapoport SI (2000) Osmotic opening of the blood-brain barrier: principles, mechanism, and therapeutic applications. Cell Mol Neurobiol 20:217-230

142. Rincon F, Mayer SA (2013) The epidemiology of intracerebral hemorrhage in the United States from 1979 to 2008. Neurocrit Care 19:95-102

143. Roda JM, Carceller F, Perez-Higueras A, Morales C (1993) Encapsulated intracerebral hematomas: a defined entity. Case report. J Neurosurg 78:829-833

144. Rodriguez-Luna D, Rubiera M, Ribo M, Coscojuela P, Pagola J, Pineiro S, Ibarra B, Meler P, Maisterra O, Romero F, AlvarezSabin J, Molina CA (2011) Serum low-density lipoprotein cholesterol level predicts hematoma growth and clinical outcome after acute intracerebral hemorrhage. Stroke; J Cereb Circ 42:2447-2452

145. Rosand J, Eckman MH, Knudsen KA, Singer DE, Greenberg SM (2004) The effect of warfarin and intensity of anticoagulation on outcome of intracerebral hemorrhage. Arch Intern Med 164:880-884

146. Rosand J, Hylek EM, O'Donnell HC, Greenberg SM (2000) Warfarin-associated hemorrhage and cerebral amyloid angiopathy: a genetic and pathologic study. Neurology 55:947-951

147. Sakaida H, Sakakura M, Tochio H, Nakao K, Taniguchi A, Yabana T (1993) Chronic encapsulated intracerebral hematoma 
associated with angiographically occult arteriovenous malformation-case report. Neurol Med Chir 33:638-642

148. Schlunk F, Van Cott EM, Hayakawa K, Pfeilschifter W, Lo EH, Foerch C (2012) Recombinant activated coagulation factor VII and prothrombin complex concentrates are equally effective in reducing hematoma volume in experimental warfarin-associated intracerebral hemorrhage. Stroke; J Cereb Circ 43:246-249

149. Silva Y, Leira R, Tejada J, Lainez JM, Castillo J, Davalos A, Stroke Project CDGotSNS (2005) Molecular signatures of vascular injury are associated with early growth of intracerebral hemorrhage. Stroke; J Cereb Circ 36:86-91

150. Sorimachi T, Fujii Y (2010) Early neurological change in patients with spontaneous supratentorial intracerebral hemorrhage. J Clin Neurosci: Off J Neurosurg Soc Australas 17:1367-1371

151. Staykov D, Wagner I, Volbers B, Hauer EM, Doerfler A, Schwab S, Bardutzky J (2011) Natural course of perihemorrhagic edema after intracerebral hemorrhage. Stroke; J Cereb Circ 42:2625-2629

152. Steiner T, Diringer MN, Schneider D, Mayer SA, Begtrup K, Broderick J, Skolnick BE, Davis SM (2006) Dynamics of intraventricular hemorrhage in patients with spontaneous intracerebral hemorrhage: risk factors, clinical impact, and effect of hemostatic therapy with recombinant activated factor VII. Neurosurgery 59:767-773 (discussion 773-764)

153. Stroke Unit Trialists $C$ (2013) Organised inpatient (stroke unit) care for stroke. Cochrane Database Syst Rev 9:CD000197

154. Sumer M, Ozdemir I, Erturk O (2003) Progression in acute ischemic stroke: frequency, risk factors and prognosis. J Clin Neurosci: Off J Neurosurg Soc Australas 10:177-180

155. Sun W, Peacock A, Becker J, Phillips-Bute B, Laskowitz DT, James ML (2012) Correlation of leukocytosis with early neurological deterioration following supratentorial intracerebral hemorrhage. J Clin Neurosci: Off J Neurosurg Soc Australas 19:1096-1100

156. Sykora M, Diedler J, Rupp A, Turcani P, Rocco A, Steiner T (2008) Impaired baroreflex sensitivity predicts outcome of acute intracerebral hemorrhage. Crit Care Med 36:3074-3079

157. Sykora M, Diedler J, Rupp A, Turcani P, Steiner T (2009) Impaired baroreceptor reflex sensitivity in acute stroke is associated with insular involvement, but not with carotid atherosclerosis. Stroke; J Cereb Circ 40:737-742

158. Sykora M, Steiner T, Poli S, Rocco A, Turcani P, Diedler J (2012) Autonomic effects of intraventricular extension in intracerebral hemorrhage. Neurocrit Care 16:102-108

159. Takeda R, Ogura T, Ooigawa H, Fushihara G, Yoshikawa S, Okada D, Araki R, Kurita H (2013) A practical prediction model for early hematoma expansion in spontaneous deep ganglionic intracerebral hemorrhage. Clin Neurol Neurosurg 115:1028-1031

160. Takeuchi S, Nawashiro H, Wada K, Takasato Y, Masaoka H, Hayakawa T, Nagatani K, Otani N, Osada H, Shima K (2013) Ventriculomegaly after decompressive craniectomy with hematoma evacuation for large hemispheric hypertensive intracerebral hemorrhage. Clin Neurol Neurosurg 115:317-322

161. Tellez H, Bauer RB (1973) Dexamethasone as treatment in cerebrovascular disease. 1. A controlled study in intracerebral hemorrhage. Stroke; J Cereb Circ 4:541-546

162. Thiex R, Tsirka SE (2007) Brain edema after intracerebral hemorrhage: mechanisms, treatment options, management strategies, and operative indications. Neurosurg Focus 22:E6

163. Thompson AL, Kosior JC, Gladstone DJ, Hopyan JJ, Symons SP, Romero F, Dzialowski I, Roy J, Demchuk AM, Aviv RI, Group PRSICS (2009) Defining the CT angiography 'spot sign' in primary intracerebral hemorrhage. Can J Neurol Sci Le journal canadien des sciences neurologiques 36:456-461

164. van Asch CJ, Luitse MJ, Rinkel GJ, van der Tweel I, Algra A, Klijn CJ (2010) Incidence, case fatality, and functional outcome of intracerebral haemorrhage over time, according to age, sex, and ethnic origin: a systematic review and meta-analysis. Lancet Neurol 9:167-176

165. Venkatasubramanian C, Mlynash M, Finley-Caulfield A, Eyngorn I, Kalimuthu R, Snider RW, Wijman CA (2011) Natural history of perihematomal edema after intracerebral hemorrhage measured by serial magnetic resonance imaging. Stroke; J Cereb Circ 42:73-80

166. Wada R, Aviv RI, Fox AJ, Sahlas DJ, Gladstone DJ, Tomlinson G, Symons SP (2007) CT angiography "spot sign" predicts hematoma expansion in acute intracerebral hemorrhage. Stroke; J Cereb Circ 38:1257-1262

167. Wagner I, Hauer EM, Staykov D, Volbers B, Dorfler A, Schwab S, Bardutzky J (2011) Effects of continuous hypertonic saline infusion on perihemorrhagic edema evolution. Stroke; J Cereb Circ 42:1540-1545

168. Wagner KR, Xi G, Hua Y, Kleinholz M, de Courten-Myers GM, Myers RE, Broderick JP, Brott TG (1996) Lobar intracerebral hemorrhage model in pigs: rapid edema development in perihematomal white matter. Stroke; J Cereb Circ 27:490-497

169. Wang J, Dore S (2007) Heme oxygenase-1 exacerbates early brain injury after intracerebral haemorrhage. Brain: J Neurol 130:1643-1652

170. Wang Y, Wang T, Zhang JH, Qin X (2011) Effects of early serum glucose levels on prognosis of patients with acute intracerebral hemorrhage. Acta Neurochir Suppl 111:393-397

171. Wijdicks EF, Fulgham JR (1995) Acute fatal deterioration in putaminal hemorrhage. Stroke; J Cereb Circ 26:1953-1955

172. Wong AA, Henderson RD, O'Sullivan JD, Read SJ, Rajah T (2004) Ring enhancement after hemorrhagic stroke. Arch Neurol 61:1790

173. Wu G, Xi G, Huang F (2006) Spontaneous intracerebral hemorrhage in humans: hematoma enlargement, clot lysis, and brain edema. Acta Neurochir Suppl 96:78-80

174. Wu H, Wu T, Xu X, Wang J, Wang J (2011) Iron toxicity in mice with collagenase-induced intracerebral hemorrhage. J Cereb Blood Flow Metab: Off J Int Soc Cereb Blood Flow Metab 31:1243-1250

175. Wu J, Hua Y, Keep RF, Schallert T, Hoff JT, Xi G (2002) Oxidative brain injury from extravasated erythrocytes after intracerebral hemorrhage. Brain Res 953:45-52

176. Xi G, Keep RF, Hoff JT (1998) Erythrocytes and delayed brain edema formation following intracerebral hemorrhage in rats. J Neurosurg 89:991-996

177. Xi G, Keep RF, Hoff JT (2006) Mechanisms of brain injury after intracerebral haemorrhage. Lancet Neurol 5:53-63

178. Xi G, Wagner KR, Keep RF, Hua Y, de Courten-Myers GM, Broderick JP, Brott TG, Hoff JT (1998) Role of blood clot formation on early edema development after experimental intracerebral hemorrhage. Stroke; J Cereb Circ 29:2580-2586

179. Yashon D, Kosnik EJ (1978) Chronic intracerebral hematoma. Neurosurgery 2:103-106

180. Yildiz OK, Arsava EM, Akpinar E, Topcuoglu MA (2012) Previous antiplatelet use is associated with hematoma expansion in patients with spontaneous intracerebral hemorrhage. J Stroke Cerebrovasc Dis: Off J Natl Stroke Assoc 21:760-766

181. Yuguang L, Liangwen Z, Fusheng L, Shugan Z, Xingang L, Wandong S, Chengyuan W (2003) Chronic expanding intracerebral hematoma. J Clin Neurosci: Off J Neurosurg Soc Australas 10:680-682

182. Zazulia AR, Diringer MN, Derdeyn CP, Powers WJ (1999) Progression of mass effect after intracerebral hemorrhage. Stroke; J Cereb Circ 30:1167-1173

183. Zhou X, Chen J, Li Q, Ren G, Yao G, Liu M, Dong Q, Guo J, Li L, Guo J, Xie P (2012) Minimally invasive surgery for spontaneous supratentorial intracerebral hemorrhage: a meta-analysis of randomized controlled trials. Stroke; J Cereb Circ 43:2923-2930 